Dana:

DOE/OR/21548-082

(CONTRACT NO. DE-ACO5-86OR21548)

\title{
EVALUATION OF RADON EMISSIONS AND POTENTIAL CONTROL REQUIREMENTS
}

For The :

Weldon Spring Site Remedial Action Project Weldon Spring, Missouri

Prepared By MK-Ferguson Company And Jacobs Engineering Group AUGUST 1989

\section{DO NOT MICROFLLM \\ COVER}

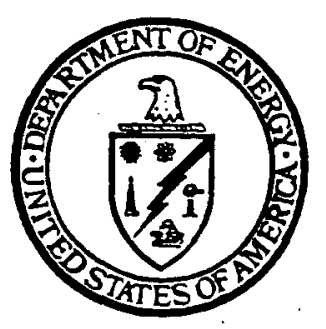

U.S. Department Of Energy

Oak Ridge Operations Office

Weldon Spring Site Remedial Action Project 
Printed in the United States of America. Available from the National Technical Information Service, NTIS, U.S. Department of Commerce, 5285 Port Royal Road, Springfield, Virginia 22161

NTIS Price Codes - Printed copy: A05 Microfiche: A01

This report was prepared as an account of work sponsored by an agency of the United States Government. Neither the United states Government nor any agency thereof, nor any of their employees, makes any warranty, express or implied, or assumes any legal liability or responsibility for the accuracy, completeness, or usefulness of any information, apparatus, products, or process disclosed, or represents that its use would not infringe privately owned rights. Reference herein to any specific commercial product, process, or service by trade name, trademark, manufacturer, or otherwise, does not necessarily constitute or imply its endorsement, recommendation, or favoring by the United states Government or any agency thereof. The views and opinions of authors expressed herein do not necessarily state or reflect those of the United States Government or any agency thereof. 
Weldon Spring Site Remedial Action Project

$\mathrm{DOE} / \mathrm{OR} / 21548--082$

DE90 001010

Evaluation of Radon Emissions and Potential

Control Requirements

August 1989

Revision 1

\author{
Prepared by \\ MK-FERGUSON COMPANY \\ and
}

JACOBS ENGINEERING GROUP

7295 Highway 94 South

st. Charles, Missouri 63303

For the

U.S. DEPARTMENT OF ENERGY

Oak Ridge Operations Office

Under Contract DE-ACO5-860R2 1548

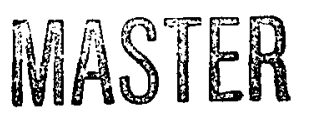

DISTRIBUTION OF THIS OOCUMENT IS UNLIAITED 


\section{Abstract}

This report provides estimates of radon release rates at the Weldon Spring Quarry (WSQ) for existing conditions and conditions which are expected to exist as the bulk waste is excavated. It also estimates radon release rates for the Temporary storage Area (TSA). In 1989, $\mathrm{Rn}-222$ concentrations at the fence line exceeded DOE guidelines. Data on working level concentrations at one monitoring station indicate an effective whole body dose rate of $0.75 \mathrm{mrem} / \mathrm{hr}$ for radon daughters and $0.74 \mathrm{mrem} / \mathrm{hr}$ for thoron daughters at one meter above the quarry waste.

Since some of the calculations are based on assumptions, they show only the relative difference in radon release between present conditions and either of two excavation scenarios. They can be used in calculations of public exposure and potential health effects to evaluate the relative merits of each excavation scenario in comparison with present release conditions.

The model used to make the estimates in this report is useful for estimating the radon release rate for the entire period of excavation, but it is not suitable for estimating worker exposure over short periods of time. Therefore, worker exposure and appropriate requirements for personal protective equipment will be determined as the excavation proceeds.

During the period of excavation, radon will be released under three conditions: (1) from the undisturbed waste during mobilization, (2) from the disturbed waste during excavation, and (3) from the undisturbed waste during excavation. In one alternative, $49.1 \mathrm{Ci}$ will be released, and in the other, $44.8 \mathrm{Ci}$ will be released. The highest annual average concentration expected at any of the fenceline monitoring stations during excavation is $2.3 \mathrm{pCi} / 1$, whereas the DOE guideline is $3 \mathrm{pCi} / 1$. The waste pile at the TSA will be covered progressively as it is constructed. Therefore, the annual radon release rate there is expected to be $4.4 \mathrm{CI}$. 
TABLE OF CONTENTS

SECTION

PAGE

1 PURPOSE, CONCLUSIONS AND RECOMMENTATIONS . . . . . . 1

1.1 Radon Monitoring Data . . . . . . . . . . . . 1

1.2 Radon Concentration Data. . . . . . . . . . . 2

1.3 Radon Flux . . . . . . . . . . . . . . . . . . 5

1.4 Working Leve1 Concentrations. . . . . . . . . 5

2 MOdeling parameters and postulated VAlues . . . . . 9

3 CALCULATION OF ESTIMATED RADON RELEASE RATE DURING

BULK WASTE EXCAVATION . . . . . . . . . . . . . . . 12

3.1 Ra-226 Total Activity . . . . . . . . . . . . 12

3.2 Radon Flux Estimation . . . . . . . . . . . . 16

3.3 Radon Release During Mobilization . . . . . . 20

3.4 Radon Release During Excavation of Disturbed

Waste .. . . . . . . . . . . . . . . . 20

3.5 Radon Release During Excavation of Undistrubed

Waste . . . . . . . . . . . . . . . . . . . . 21

3.6 Estimated Average Annual Radon Concentrations at the WSQ Fence Line . . . . . . . . . . . . 26

3.7 Radon Releases at the Temporary Storage Area. 29

4 SUMMARY . . . . . . . . . . . . . . . . . 35

5 REFERENCES . . . . . . . . . . . . . . . . . 36

Appendix A: Weldon Spring Quarry Radon Modeling

Engineering Calculations 


\section{LIST OF FIGURES}

EUMBER

PAGE

1-1 WSQ Temporary Radon/Thoron Monitoring Stations . . . 4 


\section{LIST OF TABLES}

NUMBER

PAGE

1-1 Radon Concentrations at the WSQ Fence Line . . . 3

1-2 Radon Concentrations in the WSQ . . . . . . . . 6

1-3 Results of Radon and Thoron Working Leve 1 Measurements at the WSQ . . . . . . . . . . 7

3-1 Area-Weighted Average Ra-226 Activity Concentration Within the Bulk Waste . . . . . . 14

3-2 Total Ra-226 Activity in the Bulk Waste . . . . 15

3-3 RAECOM Parameters for the WSQ Bulk Waste Excavation Under Present and Dewatered Conditions 18

3-4 RAECOM-Predicted Rn-222 Flux at the WSQ . . . . 19

3-5 Summary of Rn-222 Release for the Alternative I Scenario..................... 24

3-6 Summary of Rn-222 Release for the Alternative II Scenario..................... . 27

3-7 Predicted Annual Average Radon Concentration at the WSQ Fence Line Monitoring Station . . . . 28

3-8 Physical Description of Fine Grained Soils and Sludge in TSA storage Area....... . . . . . . 31

3-9 RAECOM Parameters for the Fine Grained Soils and Sludge in the TSA Storage Area......... . 31

3-10 RAECOM-Predicted Rn-222 Flux and Release Rate at the TSA . . . . . . . . . . . . . . . . . 32 


\section{PURPOSE, CONCLUSIONS AND RECOMMENDATIONS}

This report provides estimates of radon release rates at the Weldon spring Quarry (WSQ) for existing conditions and for conditions which are expected to exist as the bulk waste is excavated. An estimated radon release rate is also included for the Temporary Storage Area (TSA), where the excavated bulk waste will be held. Information provided to support the estimates consists of historical and present radon monitoring data, a discussion of the parameters required to predict radon fluxes, assumptions made for the two excavation scenarios, and estimated radon concentrations at the quarry fence line during bulk waste excavation. The calculated data discussed in this report will be used in subsequent environmental documents for the WSQ Bulk Waste Removal to estimate health effects on the exposed population. Radon monitoring data collected during bulk waste removal will be used to determine worker protective equipment requirements as well as acutal worker and population exposure.

\subsection{RADON MONITORING DATA}

Excavation Alternative I will release an estimated $49.1 \mathrm{Ci}$ over the estimated 52-week excavation period, plus one-week mobilization period, while Alternative II will release an estimated $44.8 \mathrm{Ci}$ over the same time period. The duration of waste removal is expected to range form 36 to 65 weeks (MKE, 1989). The radon release rate at the TSA is estimated at 44 $\mathrm{Ci} / \mathrm{yr}$. The present radon concentration at the quarry exceeds the off-site U.S. Department of Energy (DOE) guideline at one monitoring station. In order to reduce present radon releases at the WSQ and to minimize releases during bulk waste removal at the TSA, it is recommended that further consideration be given to the installation of engineering controls. 


\subsection{RADON COHCENTRATION DATA}

A radon monitoring program has been in place at the quarry since 1980. Presently, there are six permanent monitoring stations situated on the WSQ fence line (see Figure 1-1). Each station is outfitted with duplicate Terradex Track Etch Type F detectors that are exchanged on a quarterly basis. Type $F$ detectors measure ambient concentrations of both $\mathrm{Rn}-222$ (radon) and $R \mathbf{R}-220$ (thoron).

Annual average radon concentrations for each monitoring station are presented in Table 1-1. Higher than average values recorded in 1988 are due to drought conditions, which increase radon emanation rates. All concentrations include background levels (typically 0.2 to $0.6 \mathrm{pCi} / \mathrm{L}$ ). The concentration levels are due primarily to the decay of Ra-226 contained in the bulk waste. The fence line radon concentrations range from 0.28 to 4.3 pCi/1. The applicable DOE guideline for above background Rn-222 concentrations outside the quarry fence is $3 \mathrm{pCi} / 1$ on an annual average basis (Gilbert et al., 1989).

In March 1989 the project management contractor (PMC) installed Type $F$ and Type $M$ track etch detectors within the quarry in order to monitor radon and thoron concentrations directly above the bulk waste. Ten Type $F$ and 10 Type $M$ detectors were placed at five temporary monitoring stations within the quarry at a height of one meter. In addition, two Type $F$ and two Type $M$ detectors were placed at two of the stations at a height of $5 \mathrm{~cm}$ above the ground to determine if a radon or thoron gradient exists in the atmosphere directly above the bulk waste. Type $M$ detectors have a barrier which effectively screens out all thoron while allowing radon to pass through. The locations of these temporary monitoring stations are shown on Figure 1.1 . 
TABLE 1-1: Radon Concentrations at the Weldon Spring Quarry Fence Line

Monitoring Average Annual Radon Concentration ( $\mathrm{pCi} / 1)^{(a)}$

station ID $\begin{array}{lllllllll}1980 & 1981 & 1982 & 1983 & 1984 & 1985 & 1986 & 1987 & 1988\end{array}$

\begin{tabular}{|c|c|c|c|c|c|c|c|c|c|}
\hline RD- 1001 & 0.90 & 0.49 & 0.76 & 0.83 & 1.24 & 1.0 & 0.85 & 1.5 & 1.9 \\
\hline RD- 1002 &.-- & $\ldots$ & $\ldots$ & $\ldots$ & $\ldots$ & $-\ldots$ & $\ldots$ & 2.6 & 4.3 \\
\hline RD- 1003 & 0.81 & 1.15 & 1.31 & 0.68 & 0.68 & 0.7 & 0.60 & 1.5 & 2.1 \\
\hline RD- 1004 & 0.78 & 0.56 & 0.41 & 0.36 & 0.28 & 0.2 & 0.46 & 0.6 & 1.1 \\
\hline RD- 1005 & 0.50 & 0.54 & 0.49 & 0.44 & 0.79 & 0.4 & 0.43 & 0.6 & 1.0 \\
\hline RD- 1006 &.-- & $\ldots$ &.-- &.-- &.-- & $\ldots$ & $\ldots$ & 0.5 & 0.6 \\
\hline
\end{tabular}

(a) A11 measurements include background.

- Not measured.

Source: MKE and JEG, 1988; MK-Ferguson and Jacobs Engineering Group, 1989. 


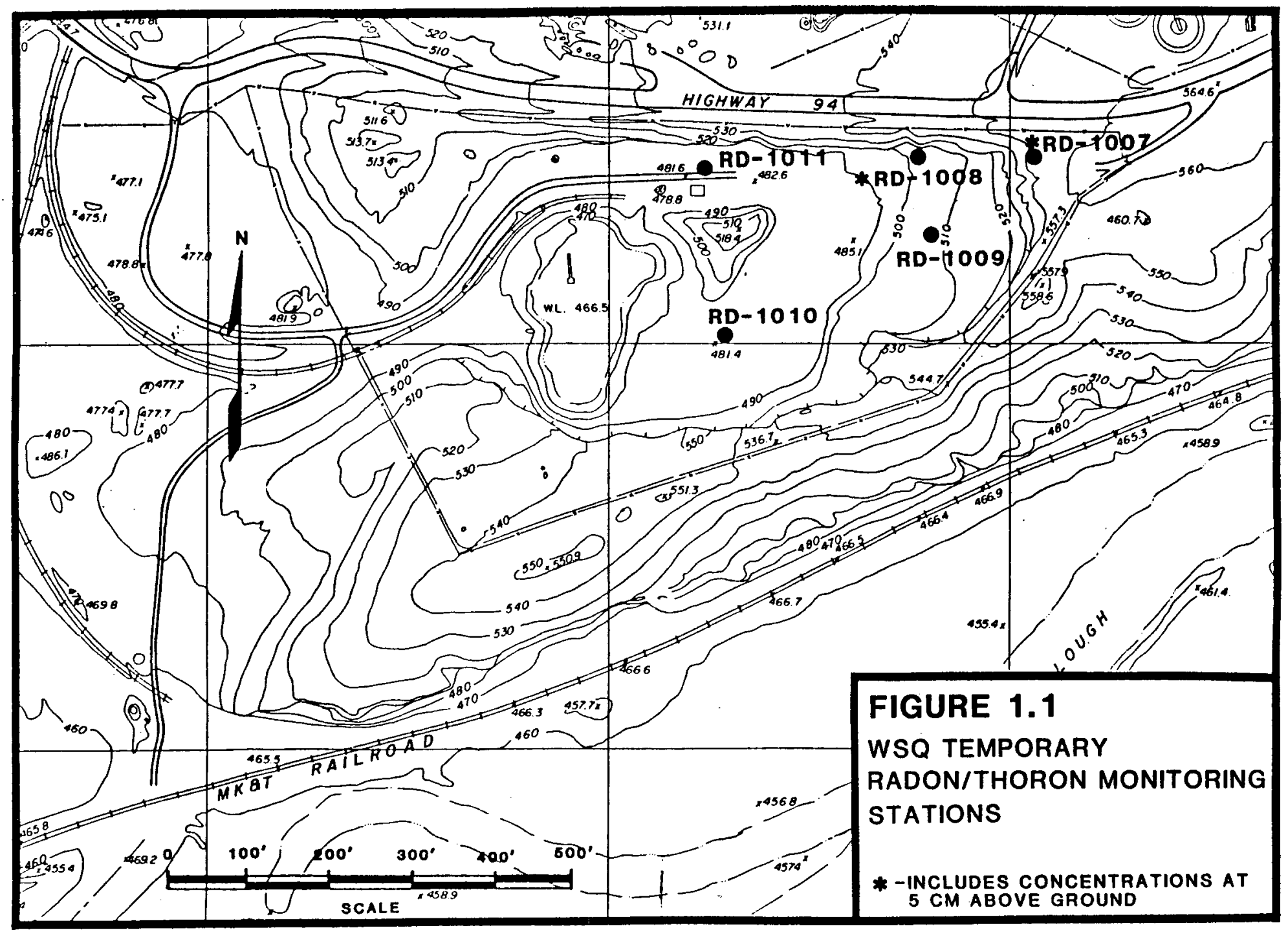


The detectors were exposed for one month and then sent to Terradex, Inc., for analysis. The analysis results (Table 1-2) indicate an elevated concentration of radon within the quarry compared to fence line concentrations and a radon gradient between the $5 \mathrm{~cm}$ and $1 \mathrm{~m}$ monitoring heights. All $1 \mathrm{~m}$ measurements are below the DOE guidelines that apply to the quarry for annual average $(30 \mathrm{pCi} / 1)$ and maximum $(100 \mathrm{pCi} / 1)$ Rn-222 concentrations (Gilbert et a1., 1989).

\subsection{RADON FLUX}

Measurements of radon flux in the quarry were made by Bechtel National, Inc., in 1985 using the charcoal canister technique. Canisters were placed on the ground and retrieved after two days of exposure. The results of these measurements ranged from 0.06 to $42.9 \mathrm{pCi} / \mathrm{m}^{2} / \mathrm{s}$ (MKE and JEG, 1989). It should be noted that radon flux is highly variable, and a two day integrating period is inadequate to assess long-term trends.

\subsection{WORRING LEVEL CONCENTRATIONS}

The PMC measured radon and thoron daughter working level (WL) concentrations at the WSQ during the periods February 10-12, 1987, and February 23 - March 31, 1989. The WSQ is divided into four zones on the basis of radiological

contamination: the northeast corner, the sump, the haulway, and the rim. (See MKE and JEG, 1989, for further information on the four quarry zones.) Measurements were taken in two zones, the sump zone and the upper gate plateau in the rim zone, at heights of $15 \mathrm{~cm}$ and $1 \mathrm{~m}$ above ground level. Sampling at the two heights was intended to identify possible thoron and/or radon daughter concentration gradients in the atmosphere immediately above ground level. Results of these measurements are presented in Table 1-3. The data are inconclusive and do not permit 
TABLE 1-2: Radon Concentrations in the Weldon Spring Quarry

\begin{tabular}{|c|c|c|c|}
\hline Temporary & & Height & $\begin{array}{c}\text { One Month } \\
\text { Average }\end{array}$ \\
\hline $\begin{array}{l}\text { Monitoring } \\
\text { Station ID }\end{array}$ & $\begin{array}{c}\text { Detector } \\
\text { Type } \\
\end{array}$ & $\begin{array}{l}\text { From } \\
\text { Ground, m }\end{array}$ & $\begin{array}{l}\text { Concentration } \\
(\mathrm{pCi} / \mathrm{L})^{(a)}\end{array}$ \\
\hline \multirow[t]{4}{*}{ RD-1007 } & $\mathbf{F}$ & 1 & 4.7 \\
\hline & M & 1 & 1.4 \\
\hline & $F$ & 0.05 & 1411.0 \\
\hline & M & 0.05 & 2063.0 \\
\hline \multirow[t]{4}{*}{ RD-1008 } & $F$ & 1 & 10.4 \\
\hline & $M$ & 1 & 6.0 \\
\hline & $F$ & 0.05 & 23.1 \\
\hline & $M$ & 0.05 & 14.9 \\
\hline \multirow[t]{2}{*}{ RD-1009 } & $F$ & 1 & 4.6 \\
\hline & $M$ & 1 & 3.7 \\
\hline \multirow[t]{2}{*}{ RD -1010} & $F$ & 1 & 2.0 \\
\hline & M & 1 & 2.3 \\
\hline \multirow[t]{2}{*}{ RD-1011 } & $F$ & 1 & 2.7 \\
\hline & $\mathbf{M}$ & 1 & 3.9 \\
\hline
\end{tabular}

(a) Reported concentrations are averages of two duplicate detectors. 
TABLE 1-3: Results of Radon and Thoron Working Level Measurements at the Weldon Spring Quarry

\begin{tabular}{|c|c|c|c|c|c|}
\hline $\begin{array}{l}\text { SAMPLE } \\
\text { DATE }\end{array}$ & $\begin{array}{l}\text { SAMPLE } \\
\text { TIME }\end{array}$ & $\begin{array}{l}\text { ZONE } \\
\text { SAMPLED }\end{array}$ & $\begin{array}{l}\text { SAMPLE } \\
\text { HEIGHT, } \mathrm{cm}\end{array}$ & $R D C^{(a)}, W L^{b}$ & $T D C^{(c)}, W L$ \\
\hline \multirow[t]{2}{*}{$02 / 10 / 87$} & 0730 & Sump & 100 & 0.07 & 0.013 \\
\hline & 1030 & Sump & 100 & 0.004 & 0.003 \\
\hline \multirow[t]{2}{*}{$02 / 11 / 87$} & 0730 & Sump & 100 & 0.13 & 0.011 \\
\hline & 1030 & Sump & 100 & 0.003 & 0.002 \\
\hline \multirow[t]{2}{*}{$02 / 12 / 87$} & 0730 & Sump & 100 & 0.07 & 0.039 \\
\hline & 1030 & Sump & 100 & 0.003 & 0.003 \\
\hline \multirow[t]{2}{*}{$02 / 23 / 89$} & 1600 & Rim & 15 & $0.001_{-4}$ & 0.003 \\
\hline & 1700 & Sump & 15 & $4 \times 10^{-4}$ & $6 \times 10^{-3}$ \\
\hline \multirow[t]{2}{*}{$02 / 24 / 89$} & 0900 & Rim & 15 & 0.003 & 0.005 \\
\hline & 1000 & Sump & 15 & $8 \times 10^{-4}$ & 0.001 \\
\hline \multirow[t]{3}{*}{$03 / 02 / 89$} & 0800 & Rim & 15 & $7 \times 10^{-4}$ & 0.003 \\
\hline & 0830 & Rim & 100 & 0.007 & $1 \times 10^{-4}$ \\
\hline & 0900 & Sump & 15 & 0.003 & 0.001 \\
\hline \multirow[t]{4}{*}{$03 / 16 / 89$} & 1530 & Rim & 15 & 0.007 & 0.002 \\
\hline & 1530 & Rim & 100 & 0.006 & 0.002 \\
\hline & 1600 & Sump & 15 & 0.001 & 0.013 \\
\hline & 1600 & Sump & 100 & 0.002 & 0.004 \\
\hline \multirow[t]{4}{*}{$03 / 17 / 89$} & 0830 & Rim & 15 & 0.003 & 0.006 \\
\hline & 0830 & Rim & 100 & 0.006 & 0.001 \\
\hline & 0900 & Sump & 15 & 0.002 & $\emptyset$ \\
\hline & 0900 & Sump & 100 & 0.002 & 0.002 \\
\hline \multirow[t]{4}{*}{$03 / 24 / 89$} & 0830 & Rim & 15 & 0.009 & $8 \times 10^{-5}$ \\
\hline & 0830 & Rim & 100 & 0.004 & $8 \times 10^{-3}$ \\
\hline & 0900 & Sump & 15 & 0.005 & 0.002 \\
\hline & 0900 & Sump & 100 & 0.003 & $8 \times 10^{-5}$ \\
\hline \multirow[t]{4}{*}{$03 / 31 / 89$} & 1300 & Rim & 15 & 0.006 & 0.002 \\
\hline & 1300 & Rim & 100 & 0.004 & 0.003 \\
\hline & 1230 & Sump & 15 & 0.004 & $6 \times 10^{-4}$ \\
\hline & 1230 & Sump & 100 & 0.003 & 0.002 \\
\hline
\end{tabular}

(a) $R D C=$ radon daughter concentrgtion

(b) WL (Working Level) $=1.3 \times 10^{5} \frac{\mathrm{MeV}}{1}$ of total alpha particle energy.

(c) $T D C=$ thoron daughter concentration

WSQRADON / TXT JOANN 
identification of a thoron daughter concentration gradient at varying heights above the ground surface.

Results ranged from $4 \times 10^{-4}$ to 0.13 WL for radon daughters and 0 to 0.039 WL for thoron daughters. A 0.13 WL radon daughter concentration would correspond to a $0.75 \mathrm{mrem} / \mathrm{hr}$ whole body equivalent dose rate using the effective dose equivalent per inhaled potential alpha energy ratio established by the International Commission on Radiological Protection (ICRP, 1981). A 0.039 WL thoron daughter concentration would correspond to a $0.074 \mathrm{mrem} / \mathrm{hr}$ whole body equivalent dose rate using the same methodology. 


\section{MOdeling parameters aNd pOStulated VALUES}

This section and Section 3 describe the assumptions and calculations used to derive the estimated radon release rate for each of the two excavation scenarios depicted in the WSQ Preliminary Design Report (MKE, 1989). These are the rates used to calculate possible health effects to the public from exposure to radon released from the quarry during bulk waste excavation. After the release rates were calculated for each excavation scenario, they were used to estimate the average annual radon concentration at the fence line during bulk waste excavation. This estimate was used to indicate whether radon concentrations may exceed DOE annual average guidelines for off-site radon release.

The WSQ Preliminary Design Report describes two possible excavation scenarios, designated Alternative $I$ and Alternative II. Alternative $I$ assumes the excavation will expose one excavation face by proceeding from the present ground level to the original quarry floor in one pass. Alternative $I$ also assumes all three major zones (northeast corner, sump, and haulway) will be excavated in this fashion. Alternative II assumes the northeast corner and haulway zones will be excavated in the same fashion as in Alternative $I$, but that the sump zone excavation will proceed in two lifts of approximately 6 meters (20 feet) each, exposing an excavation bench at the bottom of the first lift.

Before excavation begins, the bulk waste will be dewatered. A water treatment plant is planned outside the quarry for this purpose (MacDonnell et al., 1989). Dewatering will minimize the potential for further groundwater contamination by removing groundwater from the quarry. It will also allow for easier excavation of the waste. 
The estimated radon release rates for present conditions, for dewatered conditions before excavation, and for each of the two excavation scenarios under dewatered conditions are based on current data, when available, and on assumptions when current data is unavailable. Some of the assumptions are discussed in this section. A description of all assumptions used to calculate the radon release rates is provided in Appendix $A$.

Since all the calculation parameters are not based on experimental data, the rates reported in this section may not precisely model the present conditions, dewatered conditions, or dewatered conditions during excavation. Actual radon release rates under any or all of these conditions may be either higher or lower than those estimated. However, these calculations do show the relative difference in radon release between present conditions and either of the two excavation scenarios. When this difference is taken into account, the relative merits of each excavation scenario can be compared with present release conditions in calculations of public exposure and potential health effects.

The $\mathrm{Rn}-220$ (thoron) release rate has not been calculated because it is not an important parameter with respect to public exposure. Because the half-life of thoron is only 55 seconds, a significant fraction of the thoron released during excavation will decay before it reaches the fence line. In addition, the dose equivalent from exposure to thoron daughters is three times lower than that from an equal concentration of radon daughters. Daughter radionuclides constitute the main health hazard from radon and thoron (ICRP, 1981). For these reasons, thoron will not contribute significantly to public exposure and therefore is not considered.

The estimated radon release rates in this report have not been used to estimate the dose equivalent to workers. The model 
is useful for estimating the radon release rate for the entire period of excavation. However, the erratic radon hourly and daily emanation rate, combined with possible atmospheric inversions and the possibility of excavating localized areas containing higher than average Ra-226 concentrations, makes such a steady-state model unacceptable for estimating worker exposure. Therefore, worker exposure and appropriate requirements for personal protective equipment will be determined as the excavation proceeds. Real time radon and radon daughter monitoring equipment capable of supplying data on radon concentrations and working levels on an hourly basis will be used.

As can be seen by the data presented in Section 1.3, worker exposure to radon and thoron daughters would not be a problem under current conditions. An estimate of working levels during the remedial action could be made by multiplying current working levels by a ratio of calculated release rates during excavation to calculated release rates under current conditions. As shown in the following sections, the long term average radon release rates under remedial action are predicted to decrease. For this reason, worker exposure to radon daughters are likewise expected to decrease. 


\section{CALCULATION OF ESTIMATED RADON RELEASE RATE DURING BULR WASTE EXCAVATION}

In order to estimate the total radon release under present conditions and for each excavation scenario, the total Ra-226 activity within the bulk waste and the radon flux entering the atmosphere from the waste must be determined. The total Ra-226 activity determines the amount of radon released during excavation (disturbed waste), while the radon flux determines the amount of radon released from the unexcavated (undisturbed) waste. Total Ra-226 activity within the bulk waste, estimated radon flux for present and dewatered conditions, and the degree to which these parameters affect the amount of radon released from the disturbed and undisturbed volumes of bulk waste are discussed in this section.

\subsection{Ra-226 TOTAL ACTIVITY}

The Ra-226 activity in the excavated material is of prime importance in determining the radon release rate because $\mathrm{Rn}-222$ is formed directly from the radioactive decay of $\mathrm{Ra}-226$. Two major radiological investigations of the WSQ bulk waste have been performed and the results have been merged to provide an area-weighted average of $\mathrm{Ra}-226$ concentrations over the entire quarry (MRE and JEG, 1989). These averages for the surface and for subsurface depth intervals are shown in Table 3-1.

The total Ra-226 activity within the waste was estimated by multiplying the concentration at each depth interval by the average assumed density and volume of the waste: 


$$
A_{i}=p \times v_{i}
$$

where:

$$
\begin{aligned}
& A_{i}=\text { Ra-226 activity concentration at depth } i \\
& p=\text { Average bulk density }=2.2 \mathrm{~g} / \mathrm{cm}^{3} \text { (MKE and JEG, 1989) } \\
& v_{i}=\text { Volume at depth } i
\end{aligned}
$$

Equation 1 was then summed over each contamination zone. The results of this calculation are given in Table 3-2. 
TABLE 3-1 Area-Weighted Average Ra-226 Activity Concentration Within the Bulk Waste

Depth Interva1,

(m)
Area-Weighted $\mathrm{Ra}-226$

Activity Concentration

$\mathrm{pCi} / \mathrm{g}$
$0.0-0.15$
105.0
$0.15-1.5$
54.2
$1.5-3.0$
195.9
$3.0-4.6$
189.6
$4.6-6.1$
67.3
$6.1-7.6$
36.3
$7.6-9.1$
20.7
$10.7-10.7$
$20.7^{(a)}$
$11.2-11.2$
18.3

(a) No data available at this depth interval; concentration of $7.6-9.1$ meters layer assumed.

Source: MKE and JEG, 1989. 
TABLE 3-2 Total Ra-226 Activity in the Bulk Waste

\begin{tabular}{lccc} 
Zone & $\begin{array}{c}\text { Area } \\
3\end{array}$ & $\begin{array}{c}\text { Volume } \\
\mathrm{m}^{3}\end{array}$ & $\begin{array}{c}\text { Ra-226 } \\
\text { Activity } \\
\text { (Ci) }\end{array}$ \\
\hline $\begin{array}{l}\text { Haulway } \\
\text { Sump }\end{array}$ & 4,487 & 5,025 & 0.7 \\
$\begin{array}{l}\text { Northeast } \\
\text { Corner }\end{array}$ & 5,472 & 42,000 & 7.2 \\
& 4,905 & 16,250 & 4.5 \\
& 14,864 & 63,275 & 12.4 \\
\hline
\end{tabular}

Source: MKE and JEG, 1989; Appendix A. 


\subsection{RADON FLUX ESTIMATION}

The estimated radon flux under present and dewatered conditions was calculated with a PC version of the RAECOM computer model (Rogers and Nielson, 1981). The RAECOM code predicts radon $f l u x$ over areas of $\mathrm{Ra}-226$ contamination using diffusion modeling and seven physical input parameters: Ra-226 concentration, emanating fraction, diffusion coefficient, moisture content, porosity, density, and layer thickness.

The Ra-226 concentration determines the quantity of Rn-222 produced when the half-1ife of Rn-222 is taken into account. The emanating fraction is the portion of radon that escapes from soil particles into the interstitial pore spaces, which are the voids found in all soils no matter how densely compacted. Only radon entering the interstitial pore spaces is available for release to the atmosphere.

Diffusion coefficient is a measure of how fast radon moves through voids in the waste to the waste/air interface. This parameter is primarily dependent on the moisture content and porosity of the soil.

Some fraction of the total pore space volume is typically filled with water, and soil moisture content provides a measure of this fraction. Radon diffuses easier through air-filled pore spaces than water-filled ones, so the higher the soil moisture content, the lower the radon flux at the exposed surface.

Porosity is a measure of the fraction of the total volume occupied by the pore spaces. Higher porosity values mean more pore space for the radon to move through.

Density is the mass per unit volume occupied by the waste in situ. A typical mixed-grain, loose sand density was used in WSQRADON / TXTJOANN 
the RAECOM model since most radon in the WSQ bulk waste is produced and moves through the contaminated soils, not the much more dense steel and concrete rubble that is also present.

The RAECOM model requires that the contaminated volume be divided into layers. The thicknesses of the layers were chosen to coincide with those reported in the remedial investigation (MKE and JEG, 1989). A further description of each parameter, as well as the rationale used to determine each parameter value, can be found in Appendix $A$.

The RAECOM model was used to predict radon flux from the three major quarry zones before and after dewatering. The radon flux predicted under dewatered conditions was used to determine radon release for the two excavation scenarios since excavation operations will not begin unitl dewatering has been completed. Present conditions were modeled assuming no dewatering operations. The parameter values chosen to represent each major quarry zone under present and dewatered conditions are shown in Table 3-3. The predicted radon flux and annual radon release rate for each major zone under present and dewatered conditions is presented in Table 3-4.

As shown in Table 3-4, the radon fluxes used as RAECOM input Darameters are all higher than the experimentally determined fluxes discussed in Section 1.2. The flux emitted from a radon source is highly variable on a daily and even hourly basis depending on atmospheric conditions and soil moisture content. Therefore, a two day measurement of radon flux is not a reliable indicator of the average flux over the life of the proposed 53-week excavation period. The fluxes predicted by the RAECOM model represent a better average value for the excavation period and therefore were used in calculating the radon releases for the two excavation scenarios. 
Table 3-3 RAECOM Parameters for the Weldon Spring Quarry Bulk Waste Excavation Under Present and Dewatered Conditions

Layer Thickness (Feet)
\% Moisture
Present $\quad$ Dewatered
Diffusion Coefficent Present $\mathrm{cm}^{2}$ Dewatered

Sump

$\begin{array}{ll}0 & -0.5 \\ 0.5 & -5 \\ 5 & -10 \\ 10 & -15 \\ 15 & -20 \\ 20 & -25 \\ 25 & -30 \\ 30 & -35 \\ 35 & -36.7\end{array}$

10

10

10

10

10

25.3

25.3

25.3

25.3

0.018

0.025

0.05

0.05

0. 05

0.05

0.05

0.05

0.05

0.05

$1 \times 10^{-4}$

0.01

$1 \times 10^{-4}$

$1 \times 10^{-4}$

0.014

12

12

12

0.014

0.014

Northeast

Corner

$\begin{array}{ccc}0-0.5 & 10 & 8 \\ 0.5-5 & 10 & 8 \\ 5-10 & 10 & 8 \\ 10-15 & 10 & 8 \\ 15-20 & 10 & 8\end{array}$

8
8
8
8
8

0.018

0.025

0.05

0.05

0.05

0.05

0.05

0.05

80.05

0.05

Haulway

$0-0.5$
$0.5-3.7$

10

8

0.018

0.018

10

0.018

0.018

Source: MKE and JEG, 1989.

NOTE: Ra-226 concentrations in each layer are given in Table 3-1.

Porosities, emanating fractions, and soil densities are assumed to be the same for all zones and conditions. Assumed valueş are: porosity $=0.41$; emanating fraction $=0.5$; soil density $=1.6 \mathrm{~g} / \mathrm{cm}^{3}$. See Appendix A for further details. 
TABLE 3-4 RAECOM-predicted Rn-222 Flux at the Weldon Spring Quarry

\begin{tabular}{|c|c|c|c|c|c|}
\hline \multirow[t]{2}{*}{ Zone } & \multicolumn{2}{|c|}{$\begin{array}{l}\text { Radon FIUx, } \\
\left(\mathrm{pC} i / \mathrm{m}^{2} / \mathrm{S}\right)\end{array}$} & \multirow{2}{*}{$\begin{array}{l}\text { Surface } \\
\text { Area } \\
\qquad m^{2}\end{array}$} & \multicolumn{2}{|c|}{$\begin{array}{l}\text { Annual Radon } \\
\text { Release Rate, } \\
\text { (Ci/yr) }\end{array}$} \\
\hline & $\begin{array}{l}\text { Present } \\
\text { Conditions }\end{array}$ & $\begin{array}{l}\text { Dewatered } \\
\text { Conditions }\end{array}$ & & $\begin{array}{l}\text { Present } \\
\text { Conditions }\end{array}$ & $\begin{array}{l}\text { Dewatered } \\
\text { Conditions }\end{array}$ \\
\hline Haul way & 82 & 82 & 4,487 & 12 & 12 \\
\hline Sump & 237 & 250 & 5,472 & $26^{(a)}$ & 43 \\
\hline \multicolumn{6}{|c|}{ Northeast } \\
\hline Corner & 237 & 250 & 4,905 & 37 & 39 \\
\hline TOTAL & & & & 75 & 94 \\
\hline
\end{tabular}

Source: MKE and JEG, 1989.

(a) $1,988 \mathrm{~m}^{2}$ pond area not included in present annual radon release rate since pond water assumed to attenuate all Rn-222 released from pond sludge. 
The fluxes listed in Table 3-4 and the total Ra-226 activity given in Table 3-2 were used to determine the estimated total radon release for each of the two excavation scenarios, which in turn are based on the assumptions detailed in the WSQ Preliminary Design Report (MKE, 1989). A detailed account of the estimated total radon release for each scenario follows.

During the period of excavation, radon will be released under three conditions: (1) from the undisturbed waste during mobilization, (2) from the disturbed waste during excavation, and (3) from the undisturbed waste during excavation.

\subsection{RADON RELEASE DURING MOBILIZATION}

The magnitude of radon released during mobilization is the same in both scenarios. The estimated time to mobilize personnel and equipment at the quarry for either scenario is one week. During this period, all quarry zones will be emitting the undisturbed flux shown in Table 3-4, and the total radon released will be $1 / 52$ of the annual release rate, or $1.8 \mathrm{Ci}$.

\subsection{RADON RELEASE DURING EXCAVATION OF DISTURBED WASTE}

The magnitude of radon released during excavation of disturbed waste is also the same in both scenarios. The disturbed waste is assumed to release all interstitial radon upon excavation. The total estimated quantity of $\mathrm{Rn}-222$ in the material to be excavated is $12.4 \mathrm{Ci}$ (Table 3-2). This Rn-222 will be in equilibrium with the Ra-226. Based on an emanation coefficient of 0.5 (see Appendix A), the total radon that could be released from the interstitial spaces over the entire 52-week excavation period is $6.2 \mathrm{Ci}$.

When the waste is initially excavated, it will be placed on a sort pile in the quarry to allow for gross separation of 
contaminated soils and rubble (MKE, 1989). A conservative estimate for the holding time of contaminated material on the sort pile is three days. All radon produced during this period. that reaches the interstitial pore spaces is assumed to be released at the quarry when the material is being loaded into transport vehicles. The total estimated radon release from all excavated material resting on the sort pile for three days is $2.6 \mathrm{Ci}$. This release will also occur over the entire 52-week excavation period (see Appendix A).

The interstitial radon release $(6.2 \mathrm{Ci})$ and the sort pile release $(2.6 \mathrm{Ci}$ ) are the same in either scenario because in both, the same amount of contaminated material is removed, and it remains in the sort pile the same length of time.

\subsection{RADON RELEASE DURING EXCAVATION OF UNDISTURBED WASTE}

\section{Alternative I}

In Alternative $I$, excavation proceeds from the present quarry ground level to bedrock in a single pass, assuming dewatering operations are completely successful. The northeast corner is excavated first, and this requires approximately 12 weeks. The sump is next excavated in 32 weeks. Finally, the hauiway zone is excavated in about ô weeiks (Mikét, $\overline{1} \bar{y} \bar{y}$ ).

Excavation of the northeast corner is assumed to occur at a linear rate over the 12 -week period. Consequently, the surface area is reduced linearly to zero over that period. The total amount of radon released from this zone is described by the following general equation: 
$\sigma_{i} \int_{0}^{t_{i}}\left(A_{s}-\frac{A_{s}}{t_{i}} \times t\right) d t$

where:

$$
\begin{aligned}
& \emptyset=\text { Rn-222 flux for the excavated zone (Table 3-4) } \\
& \mathbf{A}_{\mathbf{s}}=\text { Surface area of the excavated zone (Table 3-4) } \\
& \mathbf{t}_{\mathbf{f}}=\text { Estimated excavation time in weeks }
\end{aligned}
$$

Integrating and solving Equation 2 with the northeast corner zone input parameters predicts a total $\mathrm{Rn}-222$ release during excavation of $4.5 \mathrm{Ci}$.

During the period of excavation in the northeast corner, the sump and haulway zones will be essentially undisturbed and will emit fluxes at the undisturbed rate shown in Table 3-4. The total Rn-222 release from the sump and haulway zones during this period is derived by multiplying the annual radon release rate (Table 3-4) for these two zones by $12 / 52$. The result is $12.6 \mathrm{Ci}$.

The 32-week period of excavation in the sump is also assumed to occur at a linear rate, and the total Rn-222 released from the sump during this period is derived by solving Equation 2 using sump zone input parameters and a 32 week excavation time. The result is $13.3 \mathrm{Ci}$.

The waste from the northeast corner will already have been transferred to the TSA when excavation commences in the sump. Hence, it will contribute no radon during the sump excavation period. However, the haulway zone will emit its undisturbed flux for $32 / 52$ of a year. This will amount to $7.2 \mathrm{Ci}$. 
Material from the haulway will be moved to the TSA in the final eight weeks of excavation. Again, it is assumed that this excavation will be performed at a uniform rate, reducing the surface area linearly to zero over the eight-week period. Solving Equation 2 for the haulway zone excavation yields a total $\mathrm{Rn}-222$ release of $0.9 \mathrm{Ci}$.

A summary of the total Rn-222 release for the bulk waste excavation under Alternative $I$ is give in Table 3-5.

\section{Alternative II}

The Alternative II scenario is an excavation performed in lifts of about 6 meters ( 20 feet). The amount of radon released during excavation of the northeast corner and haulway will be the same as in Alternative I because neither of these zones contains bulk waste at depths greater than 6 meters ( 20 feet). The sequence in which the zones will be excavated is also the same as in Alternative $I$. Therefore, the undisturbed radon release from the sump and haulway zones during excavation of the northeast corner, and from the haulway during excavation of the sump will also be the same as in Alternative $I$.

The only time when there is a difference in total radon release bet;cas tha tuo scanariss is rhen the sump zone is hoing excavated. This is because a bulk waste bench will be exposed at the 6 meter (20-foot) depth as the excavation proceeds. Waste contaminated with $R-226$ will lie beneath this bench, hence it will become a source of radon flux not found in Alternative $I$.

Since the maximum depth of contamination in the sump zone is approximately 12 meters (40 feet), and the average depth is 11 meters (37 feet) (MKE and JEG, 1989), it is assumed that each lift will contain one-half the total volume of bulk waste. It is also assumed that the surface area uncovered by the first 
TABLE 3-5: Summary of Rn-222 Release For The Alternative I Scenario

Length of Activity

Activity
(Weeks)
Rn-222 Release

(Ci)

1 Mobilization

1

1.8

2 Excavation -

Disturbed Waste:
a) Interstitial Release
52
6.2
b) Sort Pile Release
52
2.6

3 Excavation -

Undisturbed Waste:

a) Northeast Corner:

1) From Northeast

Corner

12

4.5

2) From Sump \&

Hau Iway

12

12.6

b) Sump Excavation:

1) From Sump 32

2) From Haulway

32

13.3

7.2

c) Haulway Excavation

8

0.9

TOTAL Rn-222 Release at the Quarry

49.1 Ci 
lift will be equal to the present surface area of the sump zone $\left(5,472 \mathrm{~m}^{2}\right)$; that the first lift will be completed before the second lift begins; and that each lift will take one-half the 32-week period allowed for sump excavation. Finally, it is assumed that the rate of excavation will be uniform, hence the surface area at the present ground level will be reduced at a linear rate to zero over the first 16 weeks of excavation while the surface area exposed at the 6 meter (20-foot) depth will be increased simultaneously at a linear rate to the present sump zone area.

The $R$ n-222 release from the undisturbed area of the first 1 ift is given by Equation 2 with input parameters of flux and surface area from Table 3-4 and an excavation time of 16 weeks. This results in a $R$ - 222 release from the undisturbed area of the first lift of $6.6 \mathrm{Ci}$.

As the first lift uncovers the new surface area approximately 6 meter ( 20 feet) down, the new surface will emit a Rn-222 flux whose characteristics are determined by the input parameters in Table 3-3 for the 6-to 11.2-meter (20- to 36.7-foot) layers. The RAECOM computer code predicts a Rn-222 flux of $46 \mathrm{pCi} / \mathrm{m}^{2} / \mathrm{s}$ for this newly exposed surface. (See Appendix A.) The total $\mathrm{Rn}-222$ release is given by integrating the following general equation:

$$
D \int_{0}^{t_{1}} \frac{A_{8}}{t_{1}} \times t d t
$$

where:

$$
\begin{gathered}
\emptyset=\mathrm{Rn}-222 \text { flux for the lift } 2 \text { surface area } 046 \\
\mathrm{PCi} / \mathrm{m}^{2} / \mathrm{S}
\end{gathered}
$$


$A_{s}=$ Surface area of lift $2=5,472 \mathrm{~m}^{2}$

$t_{f}=$ Estimated excavation time $=16$ weeks

Integrating and solving Equation 3 for these parameters results in a total $\mathrm{Rn}-222$ release during the 16 week period of $1.2 \mathrm{Ci}$.

The surface area of the second lift is assumed to decrease linearly to zero over the second half of the excavation period. The total $\mathrm{Rn}-222$ released from the undisturbed area is given by the integration of Equation 2 with the same parameter values used above in Equation 3. This also results in a Rn-222 release of $1.2 \mathrm{Ci}$ during the 16-week excavation period.

Table 3-6 provides a summary of the $\mathrm{Rn}-222$ release for the Alternative II scenario. Again, the only foreseeable difference in radon release between the two excavation scenarios is in the sump zone excavation phase.

\subsection{ESTIMATED AVERAge ANNUAL RADON CONCENTRATIONS AT THE WSQ FENCE LINE}

The DOE guideline for above-background annual average Rn-222 concentrations at the WSQ fence line is $3 \mathrm{pCi} / \mathrm{L}$ (Gilbert et $a 1 ., 1989)$. In order to assess $\mathrm{Rn}-222$ concentrations relative to this guideline value during bulk waste excavation, it was assumed that the average annual concentration at each fence line monitoring station is directly proportional to the annual $\mathrm{Rn}-222$ release from the bulk waste. This assumption leads to the following simple linear equation, given present fence line concentration data and estimated $R n-222$ releases:

$$
C_{e}=C_{p} \times \frac{R e}{R p}
$$

(Eq. 4) 
TABLE 3-6: Summary of Rn-222 Release for the Alternative II Scenario

$\begin{array}{ccc}\text { Length of Activity } & \text { Rn-222 Release } \\ \text { Activity } & \text { (Weeks) } & \text { (Ci) }\end{array}$

1 Mobilization

1

1.8

2 Excavation -

Disturbed Waste:
a) Interstitial release
52
6.2
b) Sort pile release
52
2.6

3 Excavation -

Undisturbed Waste:

a) Northeast Corner Exc.
1) Northeast Corner
12
4.5
2) Sump \& Haulway
12
12.6

b) Sump Excavation

1) Lift 1 Excavation

Lift 1 surface area 16

6.6

Lift 2 surface area 16

1.2

2) Lift 2 Excavation

Lift 2 surface area 16

1. 2

3) Haulway

32

7.2

c) Haulway Excavation

8

0.9

TOTAL Rn-222 release

$44.8 \mathrm{Ci}$ 
where:

$$
\begin{aligned}
\mathbf{C e}= & \text { estimated annual average radon concentration } \\
& \text { at fence } 1 \text { ine } \\
\mathbf{C P}= & \text { present average annual concentration } \\
\mathbf{R P}_{\mathbf{P}}= & \text { present annual radon release } \\
= & 75 \mathrm{Ci} \\
\mathbf{R e}= & \text { estimated radon release during excavation } \\
= & 49.1 \mathrm{Ci} \text { for Alternative } \mathrm{I} \\
= & 44.8 \mathrm{Ci} \text { for Alternative } \mathrm{II}
\end{aligned}
$$

Table 3-7 presents the annual radon concentration, averaged over 1987 and 1988, at each quarry monitoring station along with the predicted annual average concentrations for both excavation scenarios.

TABLE 3-7: Predicted Annual Average Radon Concentration at the WSQ Fence Line Monitoring Stations

Monitoring Station ID
Present Annual

Average Radon

Concentration, $\mathrm{PC} i / \mathrm{L}$
Predicted Annual Average Radon Concentration, $\mathrm{PCi} / \mathrm{L}$ Alternative I Alternative II

$\begin{array}{llll}\text { RD-1001 } & 1.7 & 1.1 & 1.0 \\ \text { RD-1002 } & 3.5 & 2.3 & 2.1 \\ \text { RD-1003 } & 1.8 & 1.2 & 1.1 \\ \text { RD-1004 } & 0.9 & 0.6 & 0.5 \\ \text { RD-1005 } & 0.8 & 0.5 & 0.5 \\ \text { RD-1006 } & 0.6 & 0.4 & 0.4\end{array}$

NOTE: These predictions are for annual averages; hourly, daily and weekly fluctuations will occur depending on atmospheric conditions, volume, and $R a-226$ concentration of material excavated. 


\subsection{RADON RELEASES AT THE TEMPORARY STORAGE AREA}

As part of the WSQ bulk waste excavation task, a temporary storage area (TSA) will be constructed at the Weldon spring Chemical Plant site. The waste will be stored at the TSA until final disposition. This action in effect moves the radon source from the quarry to the chemical plant site where it can be more effectively monitored and controlled.

The radon release rate at the TSA was first modeled without allowing for attenuating cover material. However, to provide a baseline, since a cover material will be used at the TSA, values for its effectiveness were then incorporated into the model.

The construction and storage configuration of the TSA are described in the Quarry Preliminary Design Report (MKE, 1989). It will consist of eight storage areas where the bulk waste will be segregated according to the following classifications: rock and concrete, fine grained soils, sludge, nitroaromatics, structural debris, drums and miscellaneous metals, equipment/process vessels, and clearing and grubbing material. The material in only two of these storage areas is expected to generate significant radon flux. These are the fine-grained soils and the sludge. The total Ra-226 activity within these two areas will be $12.4 \mathrm{Ci}$, the same as estimated for the quarry bulk waste, but dispersed through smaller volumes (no void spaces and no structural debris). Table 3-8 lists the physical characteristics of these materials.

The material in the rock and concrete, structural debris, miscellaneous metals, and equipment storage areas is predominantly surficially contaminated, hence the Ra-226 content is low on a volumetric or total activity basis, and the contribution to flux is also low. The nitroaromatic contaminated soils are not radiologically contaminated and so 
will not contribute to radon flux. Also, it is assumed that the material produced by clearing and grubbing operations is not significant ly radiologically contaminated.

The radon flux from the TSA was modeled using the RAECOM computer code. Table 3-9 shows the input parameters. Details concerning the selection of each parameter are in Appendix $A$.

The temporary storage pile will be constructed progressively. This will allow a temporary cover to be placed over the material as it is stockpiled leaving only the working face accessible. It is assumed that each pile will be homogenous, i.e., the Ra-226 will be uniformly mixed throughout. However, since RAECOM requires a layer value, a layer thickness of 1.5 meter ( 5 feet) was used.

The average $\mathrm{Ra}-226$ concentration in the fine-grained soils was estimated by dividing the estimated total Ra-226 activity in the quarry soils $(12.0 \mathrm{Ci})$ by the volume of material expected in 
Table 3-8: Physical Description of Fine Grained Soils and Sludge in TSA Storage Areas

\begin{tabular}{cccc} 
Storage Area Volune $(c y)^{(a, b)}$ & $\begin{array}{c}\text { Noninal Stock } \\
\text { Beight } \\
\text { (ft) }\end{array}$ & $\begin{array}{c}\text { Total Ra-226 } \\
\text { Activity } \\
(\mathrm{Ci})\end{array}$ & $\begin{array}{c}\text { Pile } \\
\text { Surface Area } \\
(\mathrm{sf})\end{array}$ \\
\hline
\end{tabular}

$\begin{array}{lrrrr}\text { Pine Grained } & & & & \\ \text { Soil } & 44,700 & 15 & 12.0 & 80,500 \\ \text { Sludge } & 4,000 & 8 & 0.4 & 13,500\end{array}$

(a) Reference MRE, 1989.

(b) Density assumed 2,700 lb/cy.

(c) Bstinated fron volune and stack height.

Table 3-9: RAECOM Parameters for the Fine Grained Soils and Sludge in the TSA Storage Areas

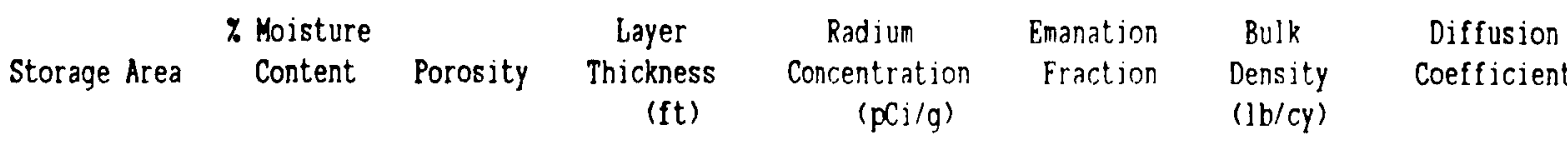

Fine Grained

$\begin{array}{rrrrrrrl}\text { Soils } & 9 & 0.41 & 5 & 219 & 0.5 & 2,700 & 0.021 \\ \text { Sludge } & 25 & 0.41 & 5 & 82 & 0.5 & 2,700 & 0.00010\end{array}$

See Appendix A 
the fine-grained soils pile $(44,700 \mathrm{cy})$ at the TSA. This resulted in a $\mathrm{Ra}-226$ concentration of $219 \mathrm{pCi} / \mathrm{g}$.

The average Ra-226 concentration of the sludge was determined in the same manner.

Table 3-10 gives the estimated Rn-222 flux from the two relevant areas. The increased flux relative to current quarry conditions is caused by concentration of the total Ra-226 activity into a smaller volume. In other words, there will be a higher activity concentration of Ra-226 in the stabilized soils at the TSA. However, only the top 1.5 meter ( 5 feet) of the pile will be of concern because the release from deeper material will be attenuated by the material above.

TABLE 3-10: RAECOM-Predicted Rn-222 Flux and Release Rate at the TSA

\begin{tabular}{lccc}
$\begin{array}{l}\text { Storage } \\
\text { Area }\end{array}$ & $\begin{array}{c}\text { Rn-222 flux } \\
\left(\mathrm{pCi} / \mathrm{m}^{2} / \mathrm{S}\right)\end{array}$ & $\begin{array}{c}\text { Surfacs } \\
\left(\mathrm{m}^{2}\right)\end{array}$ & $\begin{array}{c}\text { Area } 222 \text { Release } \\
\text { Rate }(\mathrm{Ci} / \mathrm{y})\end{array}$ \\
\hline $\begin{array}{l}\text { Fine Grained } \\
\text { Soils }\end{array}$ & 368 & 7,500 & 90 \\
Sludges & 10 & 1,250 & 0.4 \\
See Appendix A. & & &
\end{tabular}


As quarry material is relocated from the quarry to the TSA, the soils and sludge piles are assumed to increase in area linearly from zero to the values shown in Table 3-10. The flux is assumed to remain constant for each area. Therefore, in the first year of TSA operation, the total activity released will be relative to an average surface area of $7,500 \mathrm{~m}^{2} / 2$ resulting in a radon release of $44 \mathrm{Ci} / \mathrm{y}$.

A $44 \mathrm{Ci} / \mathrm{yr}$ increase in radon release from the chemical plant site would likely cause a significant increase in the site and fence line annual average radon concentrations. However, this increase will be significantly reduced by progressively covering the completed portion of the piles with an EDPM or Hypalon type of membrane. Field measurements have demonstrated that covering Ra-226 contaminated soils with EDPM membrane liners decreases radon flux by a factor of 80 (see Appendix A). This estimate is based on an average of four field measurements.

Since a comprehensive field study was not performed, a conservative factor of 10 for radon release reduction was assumed for the purposes of this report. Therefore, covering the soils and sludge piles, except the working faces, with membrane liners is expected to reduce the annual radon release rate to $4.4 \mathrm{Ci}$.

It will not be practical to cover the working face area of the soil and sludge piles during working hours. However, the radon release from this face will be small compared to the rest of the pile because the working face area will be minimized. The flux from this area will be less than that from the covered area beneath the membrane because a11 interstitial radon will be released as the haul trucks are loaded at the quarry. When the waste is deposited at the TSA working face, interstitial radon, which is the source of radon flux, will build up gradually. 
Since the working face will be covered or sprayed at the end of each day, the radon release will be attenuated before significant interstital build-up has occurred. 


\section{SUMMARY}

Excavation Alternative I will release an estimated $49.1 \mathrm{Ci}$ over the 52-week excavation period, plus one-week mobilization period, while Alternative II will release an estimated $44.8 \mathrm{Ci}$ over the same time period. The radon release rate at the TSA is estimated at $4.4 \mathrm{Ci} / \mathrm{yr}$ assuming that the pile is covered progressively. The present radon concentration at the quarry exceeds the off-site DOE guidelines at one monitoring station. These estimated radon releases warrant the consideration of engineers radon mitigation controls to reduce baseline radon levels and emissions during excavation and at the TSA. 


\section{REFERENCES}

Gilbert, T.L., C. Yu, Y.C. Yuan, A.J. Zielen, M.J. Jusko, and A. Wallo III, 1989. A Manual for Implementing Residual Radioactivity Guidelines: A Supplement to U.S. Department of Energy Guidelines for Residual Radioactive Material at Formerly Utilized Sites Remedial Action Program and Surplus Facilities Management Program Sites. ANL/ES-160; DOE/CH/8901. Prepared for the U.S. Department of Energy, Assistant Secretary for Nuclear Energy, Office of Remedial Action and Waste Technology. June.

ICRP, see International Commission on Radiological Protection.

International Commission on Radiological Protection, 1981.

Limits for Inhalation of Radon Daughters by Workers.

Publication No. 32. Pergamon Press, March.

MacDone11, M.M., J.M. Peterson, and I.E. Joya, 1989.

Engineering Evaluation/Cost Analysis for the Proposed Management of Contaminated Water in the Weldon Spring Quarry. DOE/OR/21548-039. Prepared for U.S. Department of Energy, Oak Ridge Operations Office, Weldon Spring Site Remedial Action Project, by Argonne National Laboratory, Energy and Environmental Systems Division. January.

MKE, see Morrison-Knudsen Engineers .

MKF and JEG, see MK-Ferguson Company and Jacobs Engineering Group. 
MK-Ferguson Company and Jacobs Engineering Group, 1989. Annual

Environmental Monitoring Report 1988, Rev 0.

DOE/OR/21548-079. Prepared for the U.S. Department of Energy, Oak Ridge Operations office, Weldon Spring Site Remedial Action Project. May.

MK-Ferguson Company and Jacobs Engineering Group, 1989.

Remedial Investigations for Quarry Bulk Wastes, Rev 0 . 5121R-303-066. Prepared for the U.S. Department of Energy, Oak Ridge Operations office, Weldon Spring Site Remedial Action Project.

Morrison-Knudsen Engineers, 1989. WSSRAP Quarry Preliminary Design Report. Report No. 5121R-304-00. San Francisco. May.

Rogers, V.C. and K.K. Nielson, 1981. A Handbook for the Determination of Radon Attenuation Through Cover Materials. NUREG/CR-2340, RAE18-1, PNL-4084. Prepared for the U.S. Nuclear Regulatory Commission by Rogers and Associates Engineering Corporation. 
|

i

I

I

,

I

,

I

I

I

I

I

I

,

I

I

I 


\section{APPENDIX A}

WELDON SPRING QUARRY RADON MODELING ENGINEERING CALCULATIONS

\section{WSQRADON / TXT JOANN}




\section{TOTAL RA-226 ACTIVITY WITHIN THE BULR WASTE}

In order to estimate the total $\mathrm{Rn}-222$ (radon) release from the Weldon spring Quarry (WSQ) under present conditions and for each excavation scenario, the total Ra-226 activity within the bulk waste and the radon flux entering the atmosphere must be determined. The calculation of total Ra-226 activity within the bulk waste is explained in this section, while the estimate of radon $f l u x$ is explained in Sections 2 through 5 .

The WSQ was divided into four zones of radiological contamination. Ra-226 activity was calculated for three of these zones. The fourth, the Rim Zone, was not considered because it only contains approximately $0.2 \%$ of the total waste volume.

Since excavation of the waste was assumed to proceed from zone to zone, the total Ra-226 activity within each zone was calculated using the following equation:

$$
A_{i}=c_{i} \times p \times v_{i} \times \frac{10^{6} \mathrm{~cm}^{3}}{\mathrm{~m}^{3}} \times \frac{\mathrm{mCi}}{10^{9} \mathrm{pCi}}
$$

(Eq. 1)

where:

$A_{i}=$ total activity within depth interval $i$ ( $\left.m C i\right)$.

$v_{i}=$ volume $=$ zone area $\left(\mathrm{m}^{2}\right) \mathrm{x}$ depth of interval $i(\mathrm{~m})$.

$C_{i}=$ activity concentration at depth $i(\mathrm{pCi} / \mathrm{g})$.

$p^{1}=$ density of bulk waste $\left(\mathrm{g} / \mathrm{cm}^{3}\right)$.

The results of Equation 1 were then summed over all depth intervals to arrive at the total Ra-226 activity within the zone.

The density ( $p$ ) of the waste is reported to range from 3,000 to $4,4001 \mathrm{~b} / \mathrm{cy}\left(1.78\right.$ to $\left.2.61 \mathrm{~g} / \mathrm{cm}^{3}\right)$ (MKE, 1989). The

WSQRADON/TXTJOANN A-1 
average of this range is $2.2 \mathrm{~g} / \mathrm{cm}^{3}$. This average was used to calculate total activity.

Table 1 presents activity concentrations at depth ( $\left.\mathrm{C}_{i}\right)$ averaged over the entire volume of bulk waste. Table 2 presents surface areas of the three zones for which calculations were made. Tables 3 through 5 present volumes and total Ra-226 activity contained in the Sump, Haulway, and Northeast Corner Zones, respectively.

Values were calculated using Equation 1, the activity concentrations 1 isted in Table 1 , the average assumed bulk density, and the zone surface area information listed in Table 2 . 


\section{TABLE 1: Area-Weighted Average Ra-226 Activity Concentrations Within the Bulk Waste}

Depth Interval

(m)
Ra-226 Activity

Concentration

$(\mathrm{pCi} / \mathrm{g})$
$0.0-0.15$

$0.15-1.5$

$1.5-3.0$

$3.0-4.6$

$4.6-6.1$

$6.1-7.6$

$7.6-9.1$

$9.1-10.7$

$10.7-11.2$
105.0

54.2

195.9

189.6

67.3

36.3

20.7

$20.7^{(a)}$

18.3

(a) No data available at this depth interval; concentration of layer above assumed.

Source: Table 4.6 of Draft Remedial Investigation Report for Quarry Bulk Wastes (MKE and JEG, 1989)

The concentrations reported in Table 1 were derived by area-weighting all data on bulk waste activity concentrations over the entire quarry. These concentrations were then used as average concentrations over each zone (Sump, NE Corner, and Hau 1way ). 
TABLE 2: Surface Areas of the WSQ Zones

Zone

Surface Area
$\mathrm{ft}^{2}$

Surface Area

$\mathrm{m}^{2}$

\section{Sump (including}

$\begin{array}{lll}\text { pond) } & 58,900 & 5,472 \\ \text { Haulway } & 48,300 & 4,487 \\ \text { Northeast Corner } & 52,800 & 4,905\end{array}$

Source: Table 4.7 of Draft Remedial Investigation Report for Quarry Bulk Wastes (MKF and JEG, 1989) 
TABLE 3: Volume and Total Ra-226 Activity Estimates for the Sump Zone (Not Including Pond)*

\begin{tabular}{ccr}
$\begin{array}{c}\text { Depth Interva1 } \\
(\mathrm{m})\end{array}$ & $\begin{array}{c}\text { Volume Within } \\
\text { Interval } \\
\left(\mathrm{m}^{3}\right)\end{array}$ & $\begin{array}{r}\text { Tota1 R } \\
\text { Activit } \\
(\mathrm{mCi})\end{array}$ \\
\hline $0.0-0.15$ & 531 & 123 \\
$0.15-1.5$ & 4,778 & 570 \\
$1.5-3.0$ & 5,309 & 2,288 \\
$3.0-4.6$ & 5,309 & 2,214 \\
$4.6-6.1$ & 5,309 & 786 \\
$6.1-7.6$ & 5,309 & 424 \\
$7.6-9.1$ & 5,309 & 242 \\
$9.1-10.7$ & 5,309 & 242 \\
$10.7-11.2$ & 1,805 & 73 \\
\hline
\end{tabular}

* Under present conditions, water in the pond effectively attenuates radon from that portion of the bulk waste that lies under the pond. Therefore, estimates for the pond are not included. 
TABLE 4: Volume and Total Ra-226 Activity Estimates for the Haulway Zone

\begin{tabular}{rcc}
$\begin{array}{c}\text { Depth Interval } \\
(\mathrm{m})\end{array}$ & $\begin{array}{c}\text { Volume Within } \\
\text { Interval } \\
\left(\mathrm{m}^{3}\right)\end{array}$ & $\begin{array}{c}\text { Total Ra-226 } \\
\text { Activity } \\
\text { (mCi) }\end{array}$ \\
\hline $0-0.15$ & $\underline{4,352}$ & 155 \\
$0.15-1.1$ & 5,025 & $\underline{517}$ \\
\hline
\end{tabular}


TABLE 5: Volume and Total Ra-226 Activity Estimates for the Northeast Corner Zone

$\begin{array}{ccc} & \text { Volume Within } & \text { Total Ra-226 } \\ \text { Depth Interval } & \text { Interval } & \text { Activity } \\ (\mathrm{m}) & \left(\mathrm{m}^{3}\right) & (\mathrm{mCi})\end{array}$

$0.0-0.15$

747

173

$0.15-1.5$

6,722

802

$1.5-3.0$

7,209

3,107

$3.0-4.6$

786

328

$4.6-6.1$

786

116

16,250

4,526 
Summing the total activity from Tables 3 through 5 provides a value for $\mathrm{Ra}-226$ activity which can be used to model radon release under present conditions.

Table 3 does not include an estimate of Ra-226 activity contained in the bulk waste lying under the quarry pond. This waste does not contribute to radon release at present because of attenuation from the 6 meters ( 20 feet) of water above it.

The ponded water will be removed prior to bulk waste removal. The portion of waste currently lying at the bottom of the pond will then contribute to the total radon release, effectively increasing total radon release as compared to present conditions. This additional release is accounted for in the excavation alternatives by assuming that the waste under the pond is 1.5 meters ( 5 feet) deep and contains the same Ra-226 activity concentration as the 6.1-to-7.6-meter depth interval, namely $36.3 \mathrm{pCi} / \mathrm{g}$. Applying these parameters to Equation 1 resulted in an estimated $\mathrm{Ra}-226$ activity in the waste beneath the pond of $242 \mathrm{mCi}$, and a total $\mathrm{Ra}-226$ activity within the sump zone of $7,204 \mathrm{mCi}(6,962+242)$.

The total Ra-226 activity contained within the entire quantity of bulk waste was obtained by summing the estimated activity in each of the three zones:

$$
\begin{array}{ll}
\text { Sump (incl. pond) } & =7.2 \mathrm{Ci} \\
\text { Haulway } & =0.7 \mathrm{Ci} \\
\text { NE Corner } & =4.5 \mathrm{Ci} \\
& =12.4 \mathrm{Ci}
\end{array}
$$

This $12.4 \mathrm{Ci}$ estimate was used in the calculation of radon release for two excavation scenarios.

$$
\text { WSQRADON / TXT JOANN A-8 }
$$




\section{ESTIMATED RADON FLUX WITHIN THE QUARRY}

The radon flux within the WSQ was estimated using a version of the RAECOM computer code produced by Roger Nelson, PMC ES\&H Manager. This version adapts RAECOM for personal computer (PC) use.

\subsection{Parameters}

The seven parameters required for input into the code are:

- Radium concentration within each layer ( $\mathrm{pCi} / \mathrm{g}$ )

- Emanating fraction

- Soil moisture content (as percent of dry weight)

- Soil porosity

- Density $\left(\mathrm{g} / \mathrm{cm}^{3}\right)$

- Layer thickness ( $\mathrm{cm}$ )

- Diffusion coefficient

The values for radium concentration and emanating fraction are measured values.

The values for soil moisture, soil porosity, density, layer thickness, and diffusion coefficient are based on assumptions.

\subsubsection{Radium Concentration}

Both the Lawrence Berkeley Laboratory (LBL) and Bechtel National, Inc. (BNI) obtained samples from the WSQ which were analyzed for various radionuclides including Ra-226. These data were used in the excavation model by calculating area-weighted average $\mathrm{Ra}-226$ concentrations for the depth intervals 1 isted in Table 1 . The results were used as the layer-specific radium concentrations required by the RAECOM code. 


\subsubsection{Emanating Fractions}

Emanating fractions were measured in samples taken by LBL (BGA, 1984). In the 56 samples analyzed, the average emanating fraction was 0.249 with a standard deviation of 0.167 .

On this basis, an emanating fraction of 0.5 , which is 1.5 sigma above the average, is realistic for the quarry bulk waste.

\subsubsection{Soil Moisture Content}

Assumed values for soil moisture content were based on the PMC's engineering judgement. The moisture content of sandy-clay soil material analogous to the non-rubble fraction of the bulk waste typically ranges from $5 \%$ to $15 \%$ of dry weight, assuming the material lies above the water table. The average of this range $(10 \%)$ was assumed for all waste above the water table before dewatering.

The water table begins approximately 6 meters (20 feet) below the present grade of the Sump Zone (MKE and JEG, 1989). All waste below this level was assumed to be completely saturated before dewatering. In the model, the moisture content in al1 layers below 6 meters ( 20 feet) was set equal to the saturated value in order to reflect this assumption.

It was assumed that dewatering will reduce the water content in the bulk waste to one constant quantity in the waste above the water table and another constant quantity in the waste below the water table. In the waste above the water table, this reduction is expected to be slight since this waste already has a low moisture content. Therefore, a decrease to $8 \%$ was assumed. On the other hand, dewatering will have a significant effect on the waste below the water table. The PMC estimates 
that the constant moisture content in the waste below the water table is $12 \%$. This value is confirmed in Peck (1974).

\section{1 .4 Soil Porosity}

The soil porosity parameter was determined by the equation:

$$
P=\frac{1-p^{d}}{G s}
$$

where:

$$
\begin{aligned}
& \mathrm{P}=\text { soil porosity } \\
& \mathrm{p}^{\mathrm{d}}=\text { density }\left(1.6 \mathrm{~g} / \mathrm{cm}^{3} \text { assumed }\right) \\
& \mathrm{Gs}=\text { specific gravity }(2.7 \text { assumed })
\end{aligned}
$$

The specific gravity of 2.7 was assumed because this value is representative of a sand or clay-like soil, thus consistent with the assumptions for moisture content and density. Values of specific gravity are reported in Peck (1974, p. 13) as 2.65 for sands and an average of 2.7 for clay soils.

\section{1 .5 Density}

The dry density assumed for the non-rubble fraction of the bulk waste was that given in Table 1.4 of Peck for "mixed-grained sand, loose;" namely $1.59 \mathrm{~g} / \mathrm{cm}^{3}$ rounded to two significant digits.

The bulk density range assumed in the WSQ Preliminary Design Report (MKE, 1989) of 1.78 to $2.61 \mathrm{~g} / \mathrm{cm}^{3}$ includes allowance for dense rubble such as steel and concrete. Since radon will travel through the pore space and not through the dense rubble, the soil density assumed here was more representative in predicting radon flux emanating from the bulk waste. 


\subsubsection{Layer Thiclness}

The first layer of bulk waste in the radon flux model included the first $0.15 \mathrm{~m}$ of waste. This parameter was chosen for comparative purposes only to correspond with the surface soil thickness used in the DOE guidelines for residual radionuclides in soil (Gilbert et al., 1989). The succeeding $1.5 \mathrm{~m}$ layers were chosen to correspond with typical excavation increments.

\subsubsection{Diffusion Coefficient}

The diffusion coefficient (D) came from the Nuclear Regulatory Commission handbook on radon attenuation (Rogers and Nie1son, 1981, p. xiii), which states:

"Empirical correlations for estimating $D$ (diffusion coefficient) have the advantage of being simple and easy to use, with a minimal amount of information needed. The recommended correlation using the fraction of saturation,

$\mathrm{m}$, is :

$$
D=0.07 \exp \left[-4\left(m-m P^{2}+m^{5}\right)\right]^{\prime \prime}
$$

where:

$$
\begin{aligned}
\mathbf{P} & =\text { porosity } \\
\mathbf{m} & =\text { moisture saturation fraction } \\
& =\frac{\text { dry density }\left(1.6 \mathrm{~g} / \mathrm{cm}^{3}\right)}{P} \times \text { moisture } \\
D & =\text { difusion coefficient }
\end{aligned}
$$

For percent moisture $=10: P=0.41$

$$
\begin{aligned}
& \mathrm{m}=0.39 \\
& D=0.018 \mathrm{~cm}^{2} / \mathrm{s} \quad(\text { layer } 9)
\end{aligned}
$$




$$
\text { For percent moisture }=25 \quad \begin{aligned}
P & =0.41 \\
\mathrm{~m} & =0.98 \\
\mathrm{D} & =0.0001 \text { (1ayers } 1-4)
\end{aligned}
$$

See section 2.1.3 for the justification of the value for percent of moisture.

For other layers, the diffusion coefficient (D) was chosen to account for void spaces created by rubble, rock, and steel in the waste. An average of $D$ for free air $\left(0.1 \mathrm{~cm}^{2} / \mathrm{s}\right)$ and $D$ for the Layer 9 material $\left(0.018 \mathrm{~cm}^{2} / \mathrm{s}\right)$ gives a $D$ for the middle layers of about $0.05 \mathrm{~cm}^{2} / \mathrm{s}$.

Using Equation 3, the values for D were adjusted for changes in percent of moisture.

\subsection{Estimated Radon Flux Under Present Conditions}

The assumed parameter values were entered into the PC version of RAECOM. The predicted radon flux under the assumed present (no-action) conditions was $237 \mathrm{pCi} / \mathrm{m}^{2} / \mathrm{s}$ for the sump and Northeast Corner Zones, and $82 \mathrm{pCi} / \mathrm{m}^{2} / \mathrm{s}$ for the Haulway Zone. This data is tabulated on the following output sheets. Sheet 1 represents the 11.2 meter deep Sump Zone; Sheets 2 and 3 represent the 6.1-meter and 3.0-meter sections of the Northeast Corner Zone, respectively; and Sheet 4 represents the 1.1-meter deep Haulway Zone. 
SHEET 1: Radon Flux From the Sump Zone Under Present Conditions

\begin{tabular}{|c|c|c|c|c|c|c|}
\hline \multicolumn{3}{|c|}{$\begin{array}{c}\text { Depth } \\
\text { Interval } \\
\text { (m) }\end{array}$} & \multirow{2}{*}{$\begin{array}{c}\begin{array}{c}\text { Moisture } \\
\text { Content } \\
(\%)\end{array} \\
10 \\
10 \\
10 \\
10 \\
10 \\
25.3 \\
25.3 \\
25.3 \\
25.3\end{array}$} & \multirow{2}{*}{$\begin{array}{c}\text { Ra- } 226 \\
\begin{array}{c}\text { Concentration } \\
(\mathrm{pCi} / \mathrm{g})\end{array} \\
105 \\
54 \\
196 \\
190 \\
67 \\
36 \\
21 \\
21 \\
18\end{array}$} & \multirow{2}{*}{ 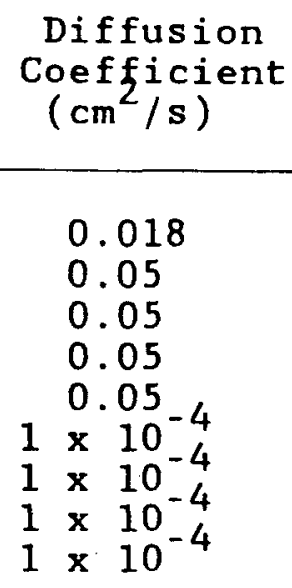 } & \multirow{2}{*}{$\begin{array}{c}\begin{array}{c}\text { Radon } \\
\text { Flux } \\
\text { (pCi/m /s ) }\end{array} \\
\\
236.9 \text { (a) } \\
213.4 \\
221.8 \\
31.5 \\
-109.12 \\
-0.0 \\
0.0 \\
0.0 \\
-0.2\end{array}$} \\
\hline $\begin{array}{l}0 \\
0.15 \\
1.5 \\
3.0 \\
4.6 \\
6.1 \\
7.6 \\
9.1 \\
10.7\end{array}$ & & $\begin{array}{l}0.15 \\
1.5 \\
3.0 \\
4.6 \\
6.1 \\
7.6 \\
9.1 \\
10.7 \\
11.2\end{array}$ & & & & \\
\hline
\end{tabular}

(a) Radon flux gmanating from the surface of the Sump Zone is $236.9 \mathrm{pCi} / \mathrm{m}^{2} / \mathrm{s}$.

The following parameters are assumed to be the same in each depth interval:

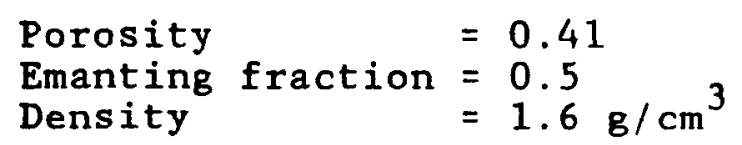


SHEET 2: Radon Flux from the Northeast Corner Zone, $6.1 \mathrm{~m}$ Region

\begin{tabular}{cccccc}
$\begin{array}{c}\text { Depth } \\
\text { Interval } \\
(\mathrm{m})\end{array}$ & $\begin{array}{c}\text { Moisture } \\
\text { Content } \\
(\%)\end{array}$ & $\begin{array}{c}\text { Ra-226 } \\
\text { Concentration } \\
(\mathrm{pCi} / \mathrm{g})\end{array}$ & $\begin{array}{c}\text { Diffusion } \\
\text { Coefficient } \\
(\mathrm{cm} / \mathrm{s})\end{array}$ & $\begin{array}{c}\text { Radon } \\
\text { Flux } \\
\left(\mathrm{pCi} / \mathrm{m}^{2} / \mathrm{s}\right)\end{array}$ \\
\hline $0-$ & 0.15 & 10 & 105 & 0.018 & $236.9(\mathrm{a})$ \\
$1.15-$ & 1.5 & 10 & 54 & 0.05 & 213.4 \\
$1.5-$ & 3.0 & 10 & 196 & 0.05 & 221.9 \\
$3.0-4.6$ & 10 & 190 & 0.05 & 31.5 \\
$4.6-6.1$ & 10 & 67 & 0.05 & -109.0 \\
\hline
\end{tabular}

Radon flux emanating from the surface of the Northeast Corner Zone, 6 -meter sector is $236.9 \mathrm{pCi} / \mathrm{m}^{2} / \mathrm{s}$.

The following parameters are assumed to be the same in each depth interval:

$$
\begin{array}{ll}
\text { Porosity } & =0.41 \\
\text { Emanting fraction } & =0.5 \\
\text { Density } & =1.6 \mathrm{~g} / \mathrm{cm}^{3}
\end{array}
$$


SHEET 3: Radon Flux From the Northeast Corner Zone, $3.0 \mathrm{~m}$ Region

\begin{tabular}{lcccc}
\hline $\begin{array}{c}\text { Depth } \\
\text { Interval } \\
(\mathrm{m})\end{array}$ & $\begin{array}{c}\text { Moisture } \\
\text { Content } \\
(\%)\end{array}$ & $\begin{array}{c}\text { Ra-226 } \\
\text { Concentration } \\
(\mathrm{pCi} / \mathrm{g})\end{array}$ & $\begin{array}{c}\text { Diffusion } \\
\text { Coefficient } \\
\left(\mathrm{cm}^{2} / \mathrm{s}\right)\end{array}$ & $\begin{array}{c}\text { Radon } \\
\text { F1ux } \\
\left(\mathrm{pCi} / \mathrm{m}^{2} / \mathrm{s}\right)\end{array}$ \\
\hline 0 & 10 & 105 & 0.018 & 229.2 (a) \\
$0.15-1.5$ & 10 & 54 & 0.05 & 205.7 \\
$1.5-3.0$ & 10 & 196 & 0.05 & 208.9 \\
\hline
\end{tabular}

Radon flux emanating from the surface of the Northeast Corner Zone, 3 -meter sector is $236.9 \mathrm{pCi} / \mathrm{m}^{2} / \mathrm{s}$.

The following parameters are assumed to be the same in each depth interval:

$$
\begin{array}{ll}
\text { Porosity } & =0.41 \\
\text { Emanting fraction } & =0.5 \\
\text { Density } & =1.6 \mathrm{~g} / \mathrm{cm}^{3}
\end{array}
$$


SHEET 4: Radon Flux From the Haulway Zone

\begin{tabular}{|c|c|c|c|c|c|c|}
\hline \multicolumn{3}{|c|}{$\begin{array}{c}\text { Depth } \\
\text { Interval } \\
\text { (m) }\end{array}$} & \multirow{2}{*}{$\begin{array}{l}\begin{array}{c}\text { Moisture } \\
\text { Content } \\
(\%)\end{array} \\
10 \\
10\end{array}$} & \multirow{2}{*}{$\begin{array}{c}\begin{array}{c}\text { Ra- } 226 \\
\text { Concentration } \\
(\mathrm{pCi} / \mathrm{g})\end{array} \\
\begin{array}{c}105 \\
54\end{array}\end{array}$} & \multirow{2}{*}{$\begin{array}{c}\begin{array}{c}\text { Diffusion } \\
\text { Coefficient } \\
\left(\mathrm{cm}^{2} / \mathrm{s}\right)\end{array} \\
\begin{array}{l}0.018 \\
0.018\end{array}\end{array}$} & \multirow{2}{*}{$\begin{array}{r}\begin{array}{c}\text { Radon } \\
\text { Flux } \\
\left(\mathrm{pCi} / \mathrm{m}^{2} / \mathrm{s}\right)\end{array} \\
\begin{array}{l}82.2^{(\mathrm{a})} \\
56.8\end{array}\end{array}$} \\
\hline $\begin{array}{l}0 \\
0.15\end{array}$ & & $\begin{array}{l}0.15 \\
1.1\end{array}$ & & & & \\
\hline
\end{tabular}

Radon flux emanating from the surface of the Haulway Zone is $82.2 \mathrm{pCi} / \mathrm{m}^{2} / \mathrm{s}$.

The following parameters are assumed to be the same in each depth interval:

$$
\begin{aligned}
\text { Porosity } & =0.41 \\
\text { Emanting fraction } & =0.5 \\
\text { Density } & =1.6 \mathrm{~g} / \mathrm{cm}^{3}
\end{aligned}
$$




\subsection{Estimated Radon Flux Under Dewatered Conditions}

Dewatering the bulk waste will result in a lower moisture content in the waste lying below the water table, and to a much lesser extent, in the waste above the water table. The moisture content in the waste below the water table was assumed to be reduced to $12 \%$ while that lying above the water table will be reduced to $8 \%$ (see Section 2.1 .3 ). The diffusion coefficients affected by the drop in moisture content were adjusted according to Equation 3 .

The above changes were entered into RAECOM (see Output Sheets 5 through 8 ). Predicted radon fluxes for dewatered conditions were: $250 \mathrm{pCi} / \mathrm{m}^{2} / \mathrm{s}$ for the Sump (Sheet 5) and Northeast Corner (Sheets 6 and 7 ), and $82 \mathrm{pCi} / \mathrm{m}^{2} / \mathrm{s}$ for the Haulway (Sheet 8 ). 
SHEET 5: Radon Flux From the Sump Zone, Dewatered Conditions

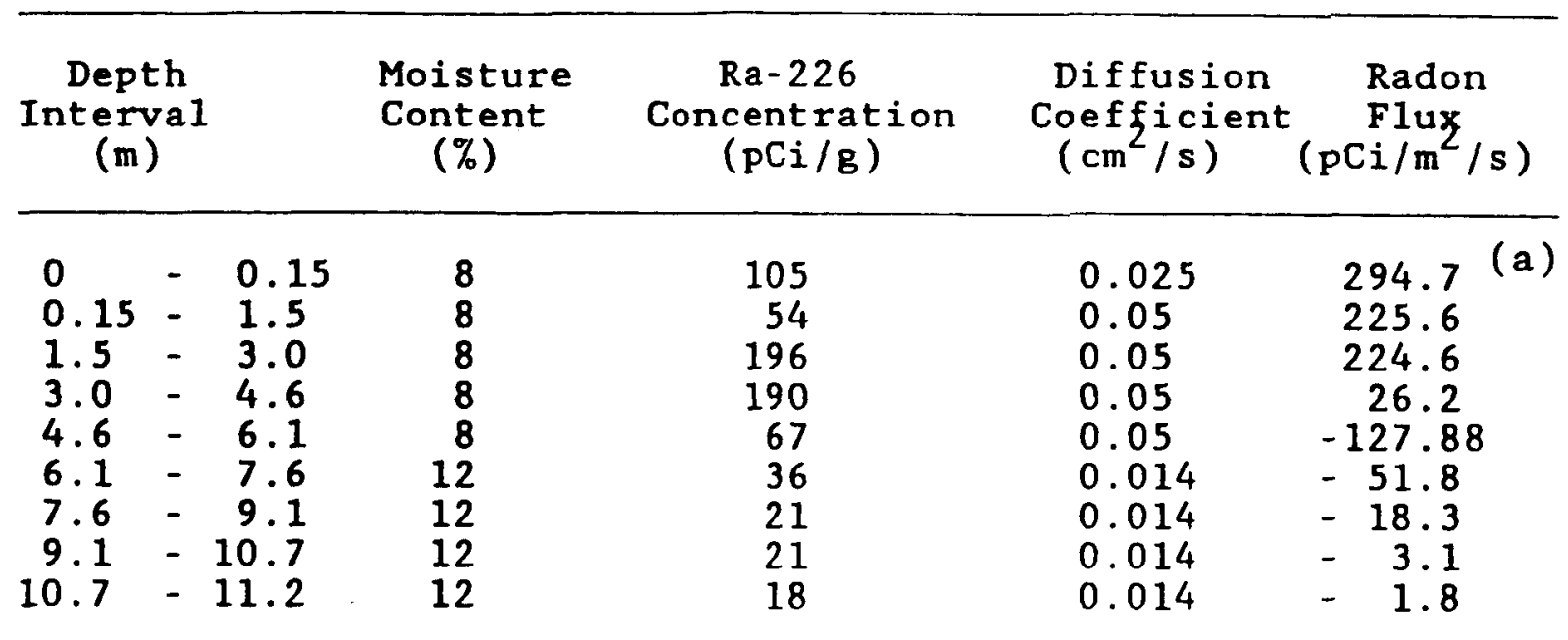

Radon flux gmanating from the surface of the Sump Zone is $294.7 \mathrm{pCi} / \mathrm{m}^{2} / \mathrm{s}$.

The following parameters are assumed to be the same in each depth interva1:

$\begin{array}{ll}\text { Porosity } & =0.41 \\ \text { Emanting fraction } & =0.5 \\ \text { Density } & =1.6 \mathrm{~B} / \mathrm{cm}^{3}\end{array}$ 
SHEET 6: Radon Flux From the Northeast Corner Zone, $6.1 \mathrm{~m}$ Region Under Dewatered Conditions

\begin{tabular}{|c|c|c|c|c|c|c|}
\hline \multicolumn{3}{|c|}{$\begin{array}{l}\text { Depth } \\
\text { Interva } 1 \\
\text { (m) }\end{array}$} & \multirow{2}{*}{$\begin{array}{c}\begin{array}{c}\text { Moisture } \\
\text { Content } \\
(\%)\end{array} \\
\\
8 \\
8 \\
8 \\
8 \\
8\end{array}$} & \multirow{2}{*}{$\begin{array}{c}\text { Ra- } 226 \\
\begin{array}{c}\text { Concentration } \\
(\mathrm{pCi} / \mathrm{g})\end{array} \\
105 \\
54 \\
196 \\
190 \\
67\end{array}$} & \multirow{2}{*}{$\begin{array}{l}\begin{array}{c}\text { Diffusion } \\
\text { Coefficient } \\
\left(\mathrm{cm}^{2} / \mathrm{s}\right)\end{array} \\
0.025 \\
0.05 \\
0.05 \\
0.05 \\
0.05\end{array}$} & \multirow{2}{*}{$\begin{array}{c}\begin{array}{c}\text { Radon } \\
\text { F1ux } \\
\left(\mathrm{pCi} / \mathrm{m}^{2} / \mathrm{s}\right)\end{array} \\
\\
251.7(\mathrm{a}) \\
227.6 \\
227.7 \\
33.7 \\
-108.3\end{array}$} \\
\hline $\begin{array}{l}0 \\
0.15 \\
1.5 \\
3.0 \\
4.6\end{array}$ & & $\begin{array}{l}0.15 \\
1.5 \\
3.0 \\
4.6 \\
6.1\end{array}$ & & & & \\
\hline
\end{tabular}

Radon flux emanating from the ${ }_{2}$ surface of the Northeast Corner Zone, 6 -meter sector is $251.7 \mathrm{pCi} / \mathrm{m}^{2} / \mathrm{s}$.

The following parameters are assumed to be the same in each depth interval:

$\begin{array}{ll}\text { Porosity } & =0.41 \\ \text { Emanting fraction } & =0.5 \\ \text { Density } & =1.6 \mathrm{~g} / \mathrm{cm}^{3}\end{array}$


SHEET 7: Radon Flux From The Northeast Corner Zone, $3.0 \mathrm{~m}$ Region Under Dewatered Conditions

\begin{tabular}{|c|c|c|c|c|c|}
\hline $\begin{array}{r}\text { Dept } \\
\text { Interv } \\
(\mathrm{m})\end{array}$ & ial & $\begin{array}{l}\text { Moisture } \\
\text { Content } \\
(\%)\end{array}$ & $\begin{array}{c}\text { Ra- } 226 \\
\text { Concentration } \\
(p C i / g)\end{array}$ & $\begin{array}{l}\text { Diffusion } \\
\text { Coefficient } \\
\left(\mathrm{cm}^{2} / \mathrm{s}\right)\end{array}$ & $=\begin{array}{l}\text { Radon } \\
\text { FluX } \\
\left(\mathrm{pCi} / \mathrm{m}^{2} / \mathrm{s}\right)\end{array}$ \\
\hline $\begin{array}{l}0 \\
0.15 \\
1.5\end{array}$ & $\begin{array}{l}-0.15 \\
-1.5 \\
-\quad 3.0\end{array}$ & $\begin{array}{l}8 \\
8 \\
8\end{array}$ & $\begin{array}{r}105 \\
54 \\
196\end{array}$ & $\begin{array}{l}0.025 \\
0.05 \\
0.05\end{array}$ & $\begin{array}{l}243.0 \text { (a) } \\
218.8 \\
213.7\end{array}$ \\
\hline
\end{tabular}

Radon flux emanating from the surface of the Northeast Corner Zone, 3 -meter sector is $243.0 \mathrm{pCi} / \mathrm{m}^{2} / \mathrm{s}$.

The following parameters are assumed to be the same in each depth interval:

$\begin{aligned} \text { Porosity } & =0.41 \\ \text { Emanting fraction } & =0.5 \\ \text { Density } & =1.6 \mathrm{~g} / \mathrm{cm}^{3}\end{aligned}$


SHEET 8: Radon Flux From the Haulway Zone Under Dewatered Conditions

\begin{tabular}{|c|c|c|c|c|c|c|}
\hline $\begin{array}{r}\text { Dept } \\
\text { Interv } \\
(\mathrm{m})\end{array}$ & thal & & $\begin{array}{l}\text { Moisture } \\
\text { Content } \\
\quad(\%)\end{array}$ & $\begin{array}{c}\text { Ra- } 226 \\
\text { Concentration } \\
(\mathrm{pCi} / \mathrm{g})\end{array}$ & $\begin{array}{l}\text { Diffusion } \\
\text { Coefficient } \\
\left(\mathrm{cm}^{2} / \mathrm{s}\right)\end{array}$ & $\begin{array}{c}\text { Radon } \\
\text { FluX } \\
\left(\mathrm{pCi} / \mathrm{m}^{2} / \mathrm{s}\right)\end{array}$ \\
\hline $\begin{array}{l}0 \\
0.15\end{array}$ & - & $\begin{array}{l}0.15 \\
1.1\end{array}$ & $\begin{array}{l}8 \\
8\end{array}$ & $\begin{array}{r}105 \\
54\end{array}$ & $\begin{array}{l}0.018 \\
0.018\end{array}$ & $\begin{array}{l}82.2^{(a)} \\
56.8\end{array}$ \\
\hline
\end{tabular}

Radon flux $_{2}$ emanating from the surface of the Haulway Zone is $82.2 \mathrm{pCi} / \mathrm{m}^{2} / \mathrm{s}$.

The following parameters are assumed to be the same in each depth interval:

$$
\begin{array}{ll}
\text { Porosity } & =0.41 \\
\text { Emanting fraction } & =0.5 \\
\text { Density } & =1.6 \mathrm{~g} / \mathrm{cm}^{3}
\end{array}
$$


3 TOTAL RADON RELEASE SOURCE TERM--NO-ACTION ALTERNATIVE

The total radon release source term is given by:

$\mathrm{T}=\emptyset \times \mathrm{A}_{\mathrm{s}} \times 3.2 \times 1010^{7} \frac{\mathrm{s}}{\mathrm{yr}} \times \frac{\mathrm{Ci}}{10^{12} \mathrm{pCi}}$

(Eq. 4)

where:

$$
\begin{aligned}
& T=\text { Total Rn-222 release source term (Ci/yr) } \\
& \left.\emptyset=\operatorname{Rn}-222 \text { flux ( } \mathrm{pCi} / \mathrm{m}^{2} / \mathrm{s}\right) \\
& A_{S}=\text { Surface area emitting flux }\left(\mathrm{m}^{2}\right)
\end{aligned}
$$




\section{TABLE 6 Total Radon Release Source Term by Zone Under Present Conditions (Using Equation 4)}

\begin{tabular}{cll}
$\begin{array}{c}\text { Radon } f l u x \\
\left(\mathrm{pCi} / \mathrm{m}^{2} / \mathrm{s}\right)\end{array}$ & $\begin{array}{l}\text { Surface } \\
\text { Zone }\left(\mathrm{m}^{2}\right)\end{array}$ & $\begin{array}{c}\text { Total Radon Release Source } \\
\text { Term for Zone (Ci/yr) }\end{array}$ \\
\hline
\end{tabular}

Sump

(less pond)

NE Corner

Haulway

Total
237

237

82 $3,484\left(^{a}\right)$

4,905

4,487

(a) The pond area is not included since the pond water is assumed to attenuate a11 radon emanating from wastes on the bottom of the pond. 


\section{TABLE 7 Total Radon Release Source Term by Zone Under Dewatered Conditions (From Equation 4)}

$\begin{array}{llll} & \text { Radon flux } & \text { Surface } & \text { Total Radon Release Source } \\ \text { Zone } & \left(\mathrm{pCi} / \mathrm{m}^{2} / \mathrm{s}\right) & \text { Area }\left(\mathrm{m}^{2}\right) & \text { Term for Zone, (Ci/yr) }\end{array}$

$\begin{array}{lrll}\text { Sump } & 250 & 5,472^{(a)} & 43 \\ \text { NE Corner } & 250 & 4,905 & 39 \\ \text { Haulway } & 82 & 4,487 & 12 \\ \text { Total } & & & 94 \mathrm{Ci} / \mathrm{yr}\end{array}$

(a) The pond area is included since the pond water will have been. removed, exposing the bulk waste within the pond and allowing radon to emanate from it. 


\section{RADON RELEASE AT THE WSQ DURING REMOVAL}

Radon can be released at the WSQ during bulk waste removal in these situations:

1. Prior to bulk waste excavation.

2. From the disturbed (excavated) bulk waste.

3. From the undisturbed bulk waste during excavation.

Two alternatives for bulk waste excavation are proposed in the WSSRAP Quarry Preliminary Design Report (MKE, 1989). In Alternative $I$, the waste will be removed vertically from the present to the original quarry $f l o o r$ in one pass. In Alternative II, the waste will be removed in two lifts, thus continuously exposing a new horizontal surface.

\subsection{Radon Release Prior to Bulk Waste Excavation}

It is estimated that the time required for mobilization prior to excavation will be one week. During this time the bulk waste will be emitting the radon flux predicted for dewatered conditions as shown in section 2.3

The total amount of radon released during mobilization (prior to excavation) was determined by multiplying the total radon release source term under dewatered conditions by $1 / 52$ of a year:

$$
\begin{aligned}
A_{\text {mob }} & =94 \mathrm{Ci} / \mathrm{yr} \times 1 / 52 \text { year } \\
& =1.8 \mathrm{Ci}
\end{aligned}
$$

Mobilization time was assumed to be the same for both alternatives. 


\subsection{Radon Release During Bulk Waste Excavation - Alternative I}

In Alternative $I$, the waste in the Sump Zone was assumed to be removed in one pass. The excavation face will extend from the level of the existing surface of the waste to the level of the original quarry floor. The other zones will also be excavated in one pass.

\subsubsection{Disturbed Waste}

The disturbed bulk waste was assumed to release a11 interstitial radon upon excavation. Since radon was assumed to be in secular equilibrium with Ra-226 within the bulk waste, the total interstitial radon release was given by:

$$
A_{\text {int }}=A_{T} \times F
$$

where:

$$
\begin{aligned}
& \mathbf{A}_{\text {int }}=\text { interstitial radon release (Ci) } \\
& \mathbf{A}_{\mathbf{T}}=\text { total Ra-226 activity (Ci) } \\
& \mathbf{F}=\text { emanating fraction }
\end{aligned}
$$

Solving Equation 6 when $A_{T}=12.4 \mathrm{Ci}$ (see section 1) and using an emanating fraction of 0.5 (see section 2.1.2):

$$
\begin{aligned}
A_{\text {int }} & =12.4 \mathrm{Ci} \times 0.5 \\
& =6.2 \mathrm{Ci}
\end{aligned}
$$

The disturbed excavated bulk waste will be sorted and held on a sort pile within the quarry before being transferred to haul trucks (MKE, 1989). The PMC estimates that a conservative assumption for this holding time is three days. During this time, radon will be formed within the waste according to the following equation: 
$A_{f}=A_{T} \times(1-\exp (-d t))$

(Eq. 7)

where:

$$
\begin{aligned}
\mathbf{A}^{T} & =\text { total Ra-226 activity (Ci) } \\
\mathbf{t} & =\text { time on sort pile ( } 3 \text { days) } \\
\mathbf{d} & =\text { radon decay constant } \\
& =0.181 / \mathrm{d}
\end{aligned}
$$

$A_{f}=$ radon activity formed within waste on sort pile (Ci)

This equation simplifies to:

$$
\begin{aligned}
A_{f} & =A_{T} \times 0.42 \\
& =12.4 \mathrm{Ci} \times 0.42 \\
& =5.2 \mathrm{Ci}
\end{aligned}
$$

It was then assumed that:

- Radon formed within waste on the sort pile will be released when the waste is loaded into haul trucks.

- The amount of radon released when the waste is dumped into the haul trucks is given by the total amount formed $\left(A_{f}\right)$ times the emanating fraction $(0.5)$.

When these assumptions are applied to Equation 7 , radon activity released from the sort pile is:

$$
A_{s p}=A_{f} \times 0.5
$$

where:

$$
A_{s p}=\text { radon activity released from waste on sort pile }
$$


Therefore:

$$
\begin{aligned}
A_{s p} & =5.2 \mathrm{Ci} \times 0.5 \\
& =2.6 \mathrm{Ci}
\end{aligned}
$$

The total radon released from disturbed waste in Alternative I is given by the sum of the interstitial release ( $A_{\text {int }}$ ) and the sort pile release $\left.A_{s p}\right)$ :

$$
\begin{aligned}
& =6.2 \mathrm{Ci}+2.6 \mathrm{Ci} \\
& =8.8 \mathrm{Ci}
\end{aligned}
$$

\subsubsection{Undisturbed Waste}

The time required for excavation of each quarry zone is estimated in the WSSRAP Quarry Preliminary Design Report (MKE, 1989). The sequence and duration of excavation are shown in Table 8 .

TABLE 8 Estimated Excavation Times

Sequence Zone Estimated Excavation Duration

1 Northeast Corner 12 weeks

2 Sump 32 weeks

3 Haulway and Rim 8 weeks

For modeling purposes the excavation was assumed to occur at a uniform rate. Thus, the surface area of the Northeast Corner Zone will decrease linearly to zero over the first 12 weeks of excavation. The Sump Zone will emit its undisturbed WSQRADON / TXTJOANN A-29 
flux during this time, then its surface area will decrease linearly to zero over the next 32 weeks of excavation. The Haulway Zone will emit its undisturbed flux over the first 44 weeks of excavation, then its surface area will decrease linearly to zero over the last eight weeks.

\subsubsection{First 12 Weeks of Excavation}

Since the rate of excavation was assumed to be uniform, the surface area of the Northeast Corner Zone was assumed to be reduced linearly to zero over the first 12 weeks. The total amount of radon released from this zone was given by solving the following integral:

$$
\begin{aligned}
& \varnothing \int_{0}^{t_{f}}\left(A_{s}-\frac{A_{s}}{t_{f}} \times t\right) d t \\
& =\frac{\emptyset \times A_{s}}{2} \times t_{f}
\end{aligned}
$$

where:

$\emptyset=$ Radon flux for the excavated zone (Table 7 )

$A_{s}=$ Surface area of the excavated zone (Table 7)

$t_{f}=$ Estimated excavation time in weeks

Solving Equation 9 with the Northeast Corner Zone input parameters predicted a total radon release of $4.5 \mathrm{Ci}$ during excavation.

The Sump and Haulway Zones will remain undisturbed during the first 12 weeks. The total radon release from these zones 
during this period was given by Equation 4 modified to a 12 week period:

$$
\begin{aligned}
R & =\left(\emptyset \times A_{s}\right)_{\text {sump }}+\left(\emptyset \times A_{s}\right)_{\text {haulway }} \times 12 \text { wk } \\
& =12.6 \mathrm{Ci}
\end{aligned}
$$

where:

$R=$ radon release from Sump and Haulway Zones during $N E$ corner excavation ( $\mathrm{Ci}$ )

$$
\begin{aligned}
& \emptyset=\text { radon flux from zone }(\text { Table } 7) \\
& A_{S}=\text { zone surface area }(\text { Table } 7)
\end{aligned}
$$

Therefore, the total radon release from the sump and Haulway Zones will be $12.6 \mathrm{Ci}$

\subsubsection{Next 32 Weeks of Excavation}

As sumptions :

- The Northeast Corner Zone will have been completely excavated.

- The Sump Zone surface area will decrease linearly to zero during this period.

The total radon released from undisturbed areas of the Sump Zone during this period is given by Equation 9 with the following Sump Zone parameter values:

$$
\begin{aligned}
& \emptyset=250 \mathrm{pCi} / \mathrm{m}^{2} / \mathrm{s}(\text { Table } 7) \\
& A_{s}=5,472 \mathrm{~m}^{2} \quad(\text { Table } 7) \\
& t_{f}=32 \text { weeks }
\end{aligned}
$$

WSQRADON / TXT JOANN 
Solving Equation 9 with these parameter values:

$$
\begin{aligned}
& =\frac{250 \mathrm{pCi} / \mathrm{m}^{2} / \mathrm{s} \times 5.472 \mathrm{~m}^{2}}{2} \times 32 \mathrm{wks} \times \frac{6 \times 10^{8} \mathrm{~s}}{w \mathrm{k}} \\
& =13.3 \mathrm{Ci}
\end{aligned}
$$

Undisturbed release from the Haulway Zone during this period was given by Equation 4 modified to a 32 -week period:

$$
R=\left(\emptyset \times A_{s}\right)_{\text {Haulway }} \times 32 \text { wk }
$$

where:

$$
\begin{aligned}
R= & \text { radon release from Haulway Zone during Sump Zone } \\
& \text { excavation (Ci) } \\
\emptyset= & \left.82 \mathrm{pCi} / \mathrm{m}^{2} / \mathrm{s} \text { (Table } 7\right) \\
A_{S}= & 4,487 \mathrm{~m}^{2}(\text { Table } 7)
\end{aligned}
$$

Solving equation 11 gave a total radon release from Haulway Zone of $7.2 \mathrm{Ci}$

\subsubsection{Final Eight Weeks}

In the final eight weeks, the Haulway surface area will decrease linearly to zero. The total radon released from undisturbed areas of the Haulway Zone during this period was given by Equation 9 with the following parameter values:

$$
\begin{aligned}
& \emptyset=82 \mathrm{pCi} / \mathrm{m}^{2} / \mathrm{s}(\text { Table } 7) \\
& \mathrm{A}_{s}=4,487 \mathrm{~m}^{2}(\text { Table } 7) \\
& t_{f}=8 \text { weeks }
\end{aligned}
$$

Solving Equation 9 with these parameter values:

$$
=82 \mathrm{pCl} / \mathrm{m}^{2} / \mathrm{s} \times 4.487 \mathrm{~m}^{2} \times 8 \mathrm{wks} \times \frac{6 \times 10^{6} \mathrm{~s}}{w \mathrm{k}}
$$




\subsubsection{Summary Radon Release in Alternative I}

The following table summarizes all radon releases in Alternative I. Interstitial and sort pile releases were assumed to be constant over the total excavation period of 52 weeks. Values are in $\mathrm{Ci}$.

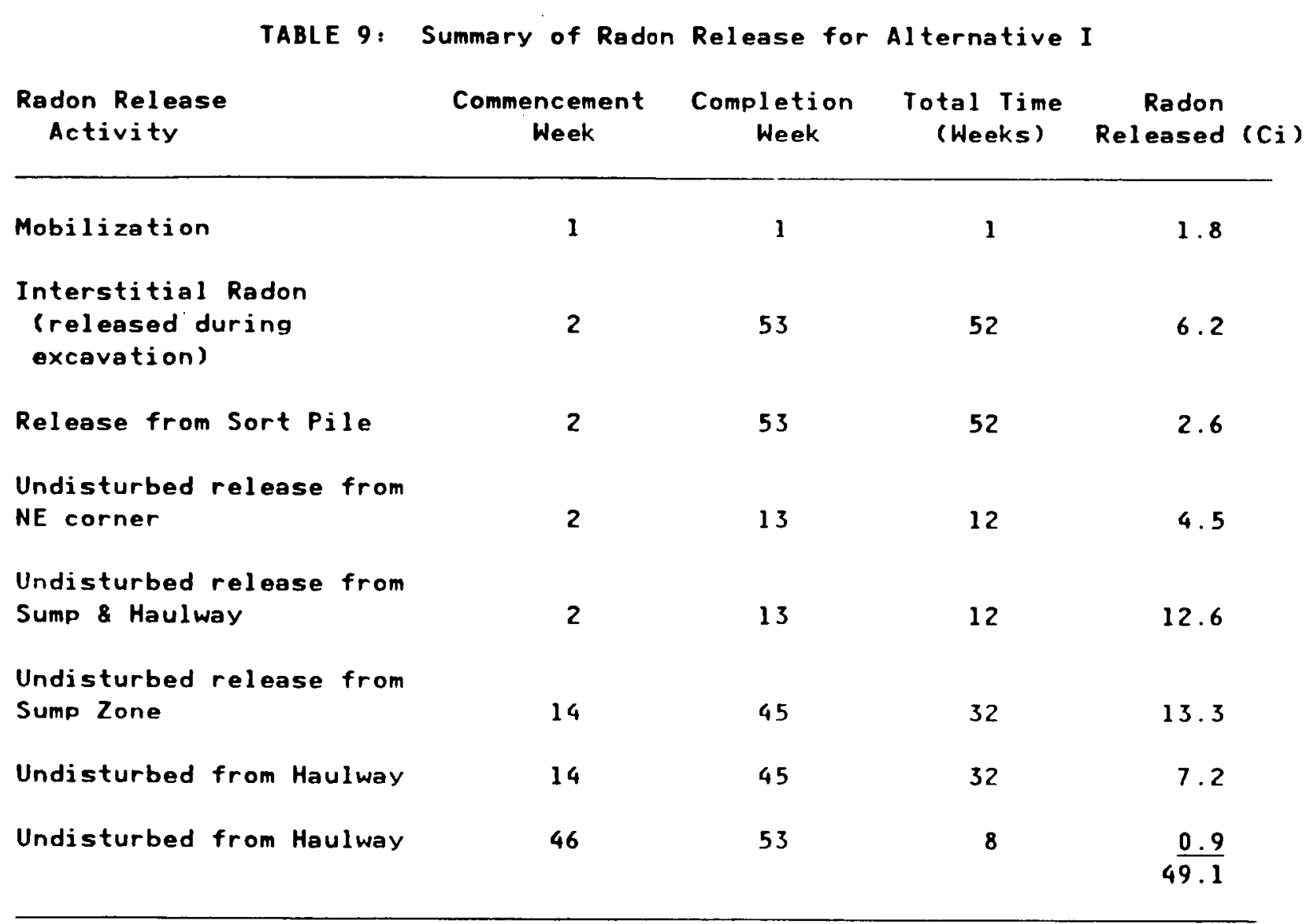


Graph of average Rn-222 release versus time for the face scenario (no engineering controls)

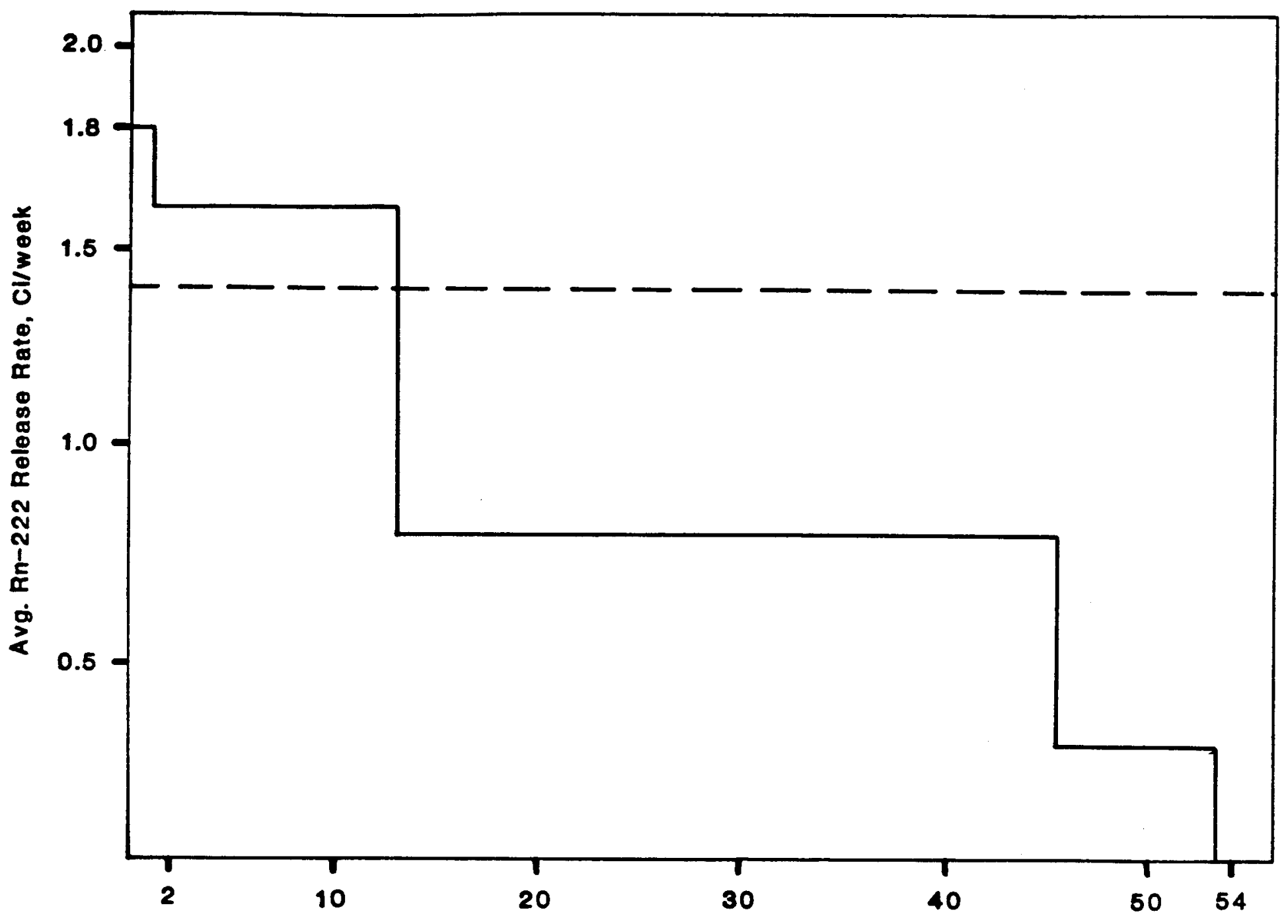

Time, Weeks

Note: Dashed line indicates estimated average radon release rate under present (non-dewatered) conditions (75 Ci/yr [see Table 6] divided by 52 wks/yr $=1.4 \mathrm{Ci} / \mathrm{wk}$ )

Note: Graph shows average $\mathrm{Rn}-222$ release rate for each activity shown in Table 9 over the total time of the activity.

FIGURE 1 


\subsection{Radon Release During Bulk Waste Excavation - Alternative II}

In Alternative II, the Sump Zone was assumed to be excavated in two 6-meter (20-foot) 1 ifts. For modeling purposes, it was assumed that the first 1 ift (0-6 meter depth) will be completed before the second is started. The total times for excavation of each zone remained the same as in Alternative I. Only the Sump Zone will be excavated in lifts since the Northeast Corner is at most 6 meters (20 feet) deep (one lift depth). Each lift in the Sump Zone will entail approximately the same area and volume, and therefore will take $1 / 2$ the total Sump Zone excavation time. The only difference in total radon release relative to Alternative $I$ will be the release due to Sump Zone excavation.

\subsubsection{Disturbed Waste}

The total interstitial radon release will be $6.2 \mathrm{Ci}$ (no change from Alternative I).

The total radon released from the sort pile will be $2.6 \mathrm{Ci}$ (no change from Alternative I).

\subsubsection{Undisturbed Waste}

\subsubsection{First 12 Weeks of Excavation}

Undisturbed waste from the Northeast Corner will release $4.5 \mathrm{Ci}$ of radon (no change from Alternative I).

Undisturbed waste from the Sump and Haulway Zones wil1 release $12.6 \mathrm{Ci}$ of radon (no change from Alternative I). 


\subsubsection{Next 32 Weeks of Excavation}

As sumptions :

- Sump zone excavated in two 6 meter (20-foot) lifts.

- Lift 1 completed before Lift 2 begins.

- Each 1ift wi11 take $1 / 2$ of total excavation time (16 weeks).

- Lift 2 waste will emit its predicted flux (see Output Sheet 9) as soon as it is uncovered.

\section{First 16 weeks:}

The surface area of Lift 1 will decrease linearly to zero over this period. At the same time, the uncovered surface area of Lift 2 will increase linearly from zero to $5,472 \mathrm{~m}^{2}$ (the area of the Sump Zone).

The diffusion coefficient used on Output sheet 9 was given by Equation 3:

$D=0.07 \exp \left[-4\left(m-m p^{2}+m^{5}\right)\right]$

where:

$$
\begin{aligned}
& \mathbf{m}=\text { moisture saturation fraction } \\
& \mathbf{p}=\text { porosity }
\end{aligned}
$$

The total radon release from Lift 1 was given by Equation 9 with the following parameter values: 


$$
\begin{aligned}
& \emptyset=250 \mathrm{pCi} / \mathrm{m}^{2} / \mathrm{s} \\
& A=5,472 \mathrm{~m}^{2} \\
& t_{f}=16 \text { weeks }
\end{aligned}
$$

Solving equation 9 with these parameter values:

$$
\begin{aligned}
& =250 \mathrm{pCi} / \mathrm{m}^{2} / \mathrm{s} \times 5.472 \mathrm{~m}^{2} \times 16 \mathrm{wks} \times \frac{6 \times 10^{8} 8}{w k} \\
& =6.6 \mathrm{Ci}
\end{aligned}
$$

The linear increase of the Lift 2 surface area will follow this equation:

$$
\int_{0}^{t_{1}} \frac{A_{8}}{t_{1}} \times t d t
$$

(Eq. 12)

where:

$$
\begin{aligned}
& \emptyset \quad=\text { radon } f l u x \text { for the lift } 2 \text { surface } \\
& \text { area }=46 \mathrm{pCi} / \mathrm{m}^{2} / \mathrm{s} \\
& A_{s}=\text { Surface area of Lift } 2=5,472 \mathrm{~m}^{2} \\
& t_{f}=\text { Estimated excavation time } 16 \text { weeks }
\end{aligned}
$$

Intergrating and solving Equation 12 for these parameters resulted in a total radon release during the 16 week period of $1.2 \mathrm{Ci}$.

\section{Last 16 weeks:}

As Lift 2 is excavated, the surface area will decrease linearly to zero.

The total radon release from Lift 2 was given by Equation 9 with the following parameter values: 


$$
\begin{aligned}
& \emptyset=46 \mathrm{pCi} / \mathrm{m}^{2} / \mathrm{s} \\
& \mathbf{A}^{\mathbf{s}}=5,472 \mathrm{~m}^{2} \\
& \mathbf{t}_{\mathbf{f}}=16 \text { weeks }
\end{aligned}
$$

Solving Equation 9 with these parameter values:

$=\frac{46 \mathrm{pCl} / \mathrm{m}^{2} / 8 \times 5,472 \mathrm{~m}^{2}}{2} \times 16 \mathrm{wks} \times \frac{6 \times 10^{5} 8}{w \mathrm{k}}$

$=1.2 \mathrm{Ci}$

Radon release from the Haulway Zone during the 32 -week Sump Zone excavation will be $7.2 \mathrm{Ci}$ (no change from Alternative I).

\subsubsection{Final Eight Weeks of Excavation}

Radon released from undisturbed waste in the Haulway Zone will be $0.9 \mathrm{Ci}$ (no change from Alternative I).

\subsubsection{Summary of Radon Release in Alternative II}

The following is a summary of all radon releases in Alternative II. Interstitial and sort pile releases were assumed to be constant over the total excavation period of 52 weeks. Values are in $\mathrm{Ci}$. 
Output Sheet 9: Radon Flux From Lift 2 of the Sump Zone

\begin{tabular}{rcccc}
$\begin{array}{c}\text { Depth } \\
\text { Interval } \\
(\mathrm{m})\end{array}$ & $\begin{array}{c}\text { Moisture } \\
\text { Content } \\
(\%)\end{array}$ & $\begin{array}{c}\text { Ra-226 } \\
\text { Concentration } \\
(\mathrm{pCi} / \mathrm{g})\end{array}$ & $\begin{array}{c}\text { Diffusion } \\
\text { Coefficient } \\
(\mathrm{cm} / \mathrm{s})\end{array}$ & $\begin{array}{c}\text { Radon } \\
\text { Flux } \\
\left(\mathrm{pCi} / \mathrm{m}^{2} / \mathrm{s}\right)\end{array}$ \\
\hline $6.1-7.6$ & 12 & 36 & 0.014 & $45.6(\mathrm{a})$ \\
$7.6-9.1$ & 12 & 21 & 0.014 & -2.8 \\
$9.1-10.7$ & 12 & 21 & 0.014 & - \\
$10.7-11.2$ & 12 & 18 & 0.014 & -2.1
\end{tabular}

Radon flux emanating from the surface of Lift 2 is $45.6 \mathrm{pCi} / \mathrm{m}^{2} / \mathrm{s}$. The following parameters were assumed to be the same in each depth interval:
Porosity $\quad=0.41$
Emanting fraction $=0.5$
Density $=1.6 \mathrm{~B} / \mathrm{cm}^{3}$ 
TABLE 10: Summary of Radon Release for Alternative II

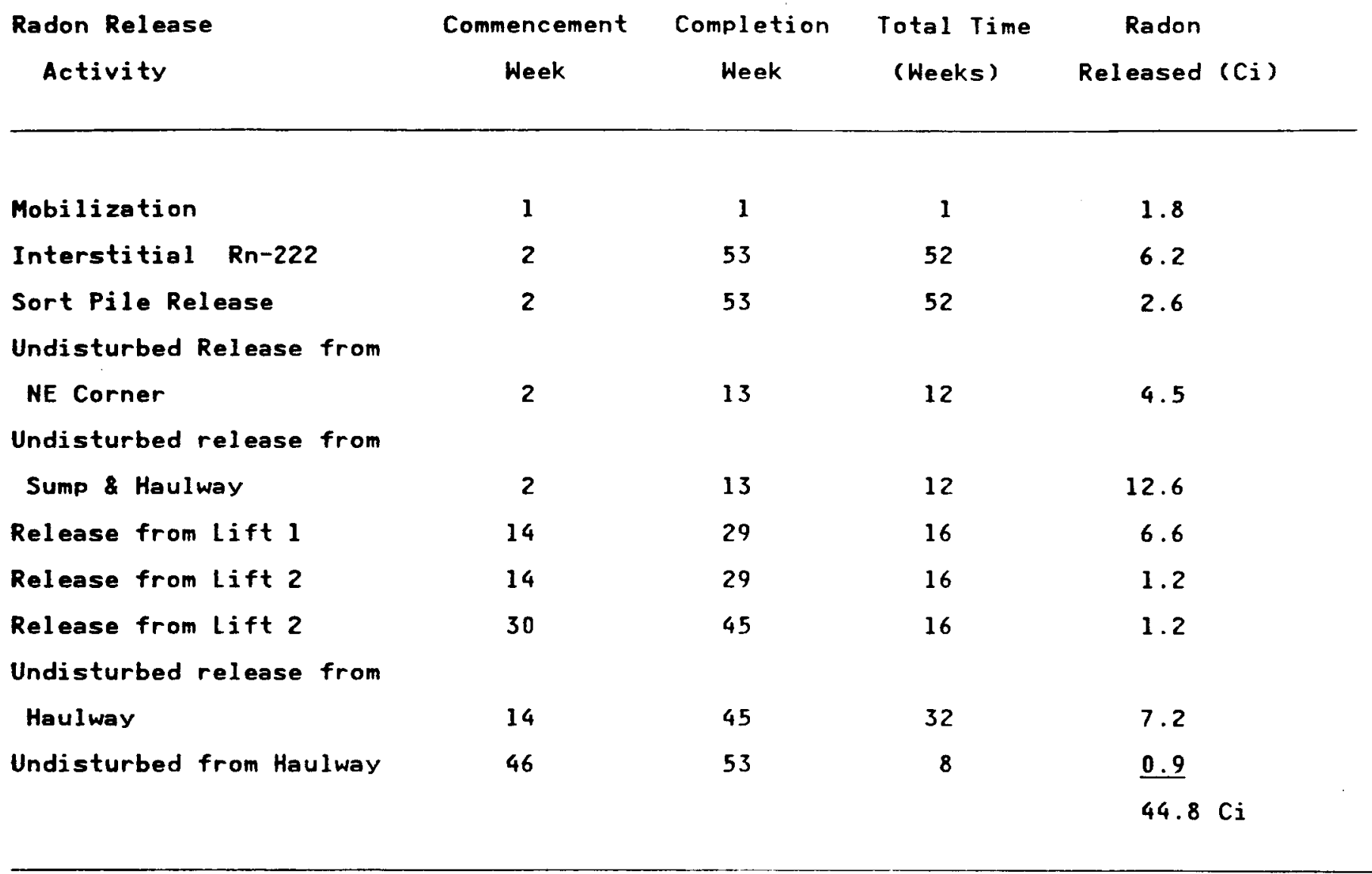


Graph of average Rn-222 release versus time for the uft scenario (no engineering controls)

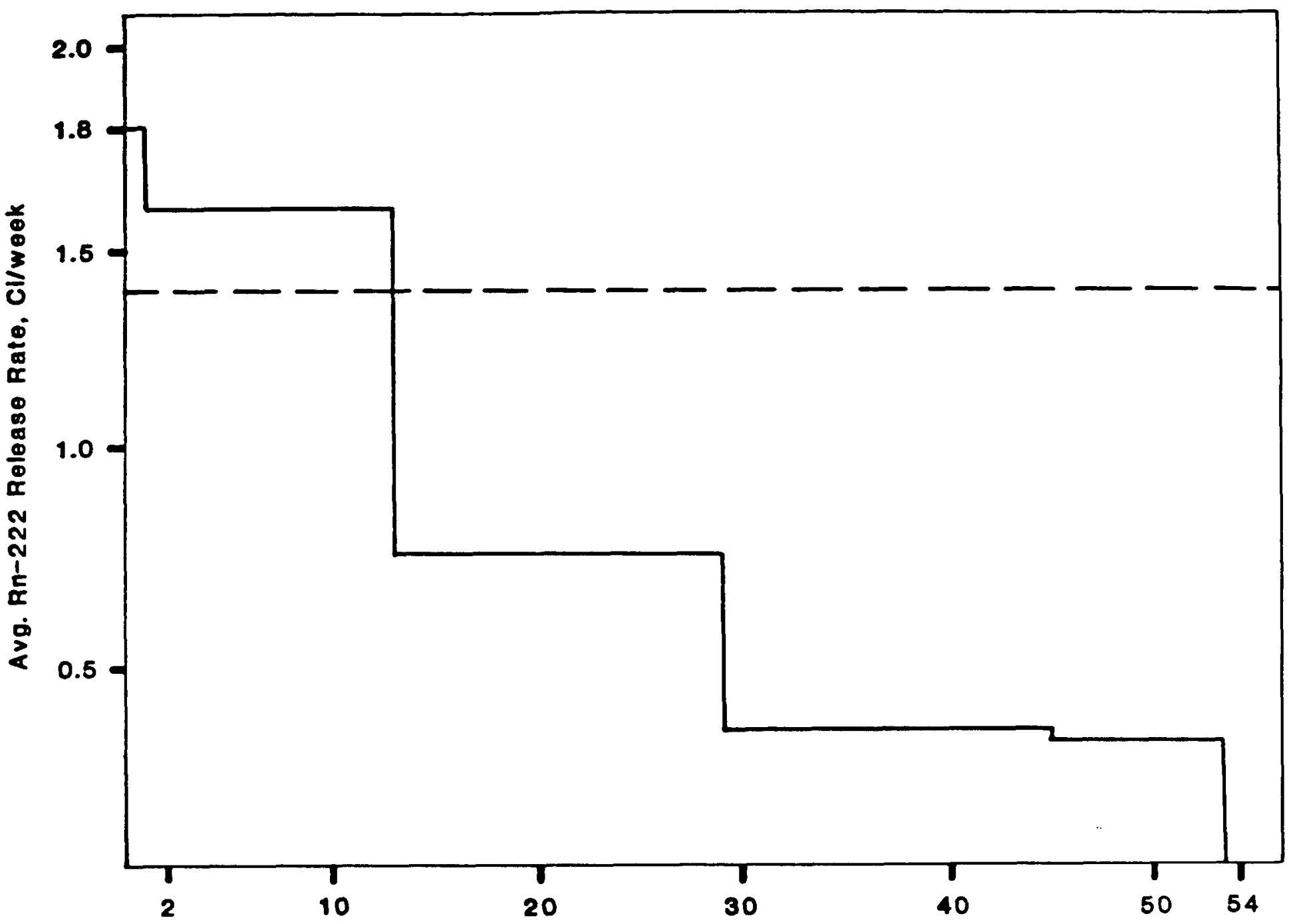

Time, Weeks

Note: Dashed line indicates estimate average $\mathrm{Rn}-222$ release rate under present conditions.

Graph shows average Rn-222 release rate for each activity shown in Table 6 over the total time of the activity.

FIGURE 2

$$
\text { WSQRADON / TXT JOANN A-41 }
$$




\section{USE OF ENGINEERING CONTROL: ETHYLENE PROPYLENE DIENE MONOMER SYNTHETIC MEMBRANE COVER}

\subsection{AsSUMPTIONS}

The following information on ethylene propylene diene monomer (EPDM) synthetic membrane was obtained from a telephone conversation with Jack Beck of Bechtel National, Inc. (BNI).

- Used by BNI at sites in Maywood and Middlesex, NJ.

- Used primarily for erosion and moisture control.

- Holding up well; has been in place approximately eight years.

- Four measurements made with charcoal canisters to determine radon reduction. (S1it made in cover and two canisters placed on top of waste; remaining two canisters placed directly on EPDM to provide measurement of radon flux passing through the membrane cover.)

- Average resu1ts: Uncovered $=40 \mathrm{pCi} / \mathrm{m}^{2} / \mathrm{s}$

- Experimental reduction factor $=80$.

- EPDM thickness used was $60 \mathrm{mil}$ (1/16 inch).

- Cost: $\$ 0.60 / f t^{2}$.

Since BNI made only four measurements, a conservative reduction factor of 10 was used in the WSQ model. This factor was cited by John Peterson of the ANL in a telephone conservation on March 13, 1989.

WSQRADON / TXT JOANN

A- 42 
It was assumed that $60,000 \mathrm{ft}^{2}$ of EPDM wil1 be required to cover the Sump Zone during excavation of the Northeast Corner Zone. The factor of 10 reduction will decrease radon release from $9.9 \mathrm{Ci}$ to $1 \mathrm{Ci}$ in both alternatives. This will cut total radon released by about $20 \%$ in Alternative $I$ and about $22 \%$ in Alternative II.

It was also assumed that the the Northeast Corner and Haulway Zones will not be covered during bulk waste excavation because no estimate could be made of the surface area required by the heavy construction equipment involved. This estimate will be more easily obtained as the waste removal operation is designed in more detail. At present, however, it is reasonable to expect that some fraction of the area in both zones will be kept covered during excavation, thus reducing radon release by percentages even greater than those herein calculated.

\subsection{Prediction of Average Annual Radon Concentration at Fence Line}

In calculating the annual radon concentration at the fence line, it was assumed that the concentrations measured at the present monitoring stations are due entirely to WSQ bulk waste and that the average annual concentrations are proportional to the total radon release. Therefore:

$$
V=\frac{\mathbf{A} \times \mathbf{R}}{\mathbf{R}_{\text {ap }}}
$$

WSQRADON / TXT JOANN A-43 
where:

$\mathrm{V}=$ Predicted average annual radon concentration at monitoring stations.

$A=$ Present average annual concentration (Average of 1987-1988 data - 8 quarters)

$R_{\mathbf{x}}=$ Radon release during excavation (Alternative $I=$ 49.1 Ci (see Section 4.2.1.3 Alternative II = 44.8 Ci (see Section 4.2.3)

$R_{\text {ap }}=$ Present annual radon release $(75 \mathrm{Ci} / \mathrm{yr}$ - see Section 3)

TABLE 11: Predicted Average Annual Radon Concentrations at Quarry Fence Line Monitoring Stations

$\begin{array}{cccc}\text { Monitoring } & \text { Present Avg. } & \text { Predicted Avg. Annual Conc. } \\ \text { Station } & \text { Annual Conc. } & \text { Alternative I } & \text { Alternative II } \\ & (\mathrm{pCi} / \mathrm{L}) & (\mathrm{pCi} / \mathrm{L}) & (\mathrm{pCi} / \mathrm{L})\end{array}$

$\begin{array}{llll}\text { RD-1001 } & 1.7 & 1.1 & 1.0 \\ \text { RD }-1002 & 3.5 & 2.3 & 2.1 \\ \text { RD- } 1003 & 1.8 & 1.2 & 1.1 \\ \text { RD- } 1004 & 0.9 & 0.6 & 0.5 \\ \text { RD- } 1005 & 0.8 & 0.5 & 0.5 \\ \text { RD }-1006 & 0.6 & 0.4 & 0.4\end{array}$

Note: Predictions are annual averages. Hourly, daily, and weekly fluctuations will occur depending on volume and Ra-226 concentration of material excavated. 


\subsection{Radon Flux from Temporary Storage Area}

The areas at the TSA that will control radon flux are (MKE, 1989):
Area B: Fine-grained soil
$44,700 \mathrm{cy}$
Area C: Sludge
$4,000 \mathrm{cy}$

The other areas were not considered for the following reasons:

Area A: Rock and concrete - predominantly surficially contaminated; so on volumetric basis, the radium content is low.

Area D: Nitroaromatics - not radiologically contaminated.

Areas E, F, G: Structural debris - See Area A.

Area H: Clearing and grubbing - See Area D.

The total activity will be the same as that estimated for both excavation alternatives but dispersed throught a smaller volume because void spaces and structural debris will have been eliminated.

\subsubsection{Total Activity Estimate}

The total activity at the TSA was estimated at $12.4 \mathrm{Ci}$ Ra-226 (see Section 1).

The depth of contaminated material at each TSA area containing signficiant Ra-226 will be (MKE, 1989): 
Area B: 4.5 meters ( 15 feet)

Area C: 2.4 meters ( 8 feet)

The surfaces of these areas are estimated to be:

Area B: $44,700 \mathrm{cy} \times 27 / \mathrm{cf} / 15 \mathrm{ft}=80,500 \mathrm{ft}^{2}=7,500 \mathrm{~m}^{2}$ Area C: $4,000 \mathrm{cy} \times 27 / \mathrm{cf} / 8 \mathrm{ft}=13,500 \mathrm{ft}^{2}=1,250 \mathrm{~m}^{2}$

The radon flux from each of these areas as modeled by RAECOM will be:

Area B: Soil moisture content $=9 \%$ (See Section 2.1.3)

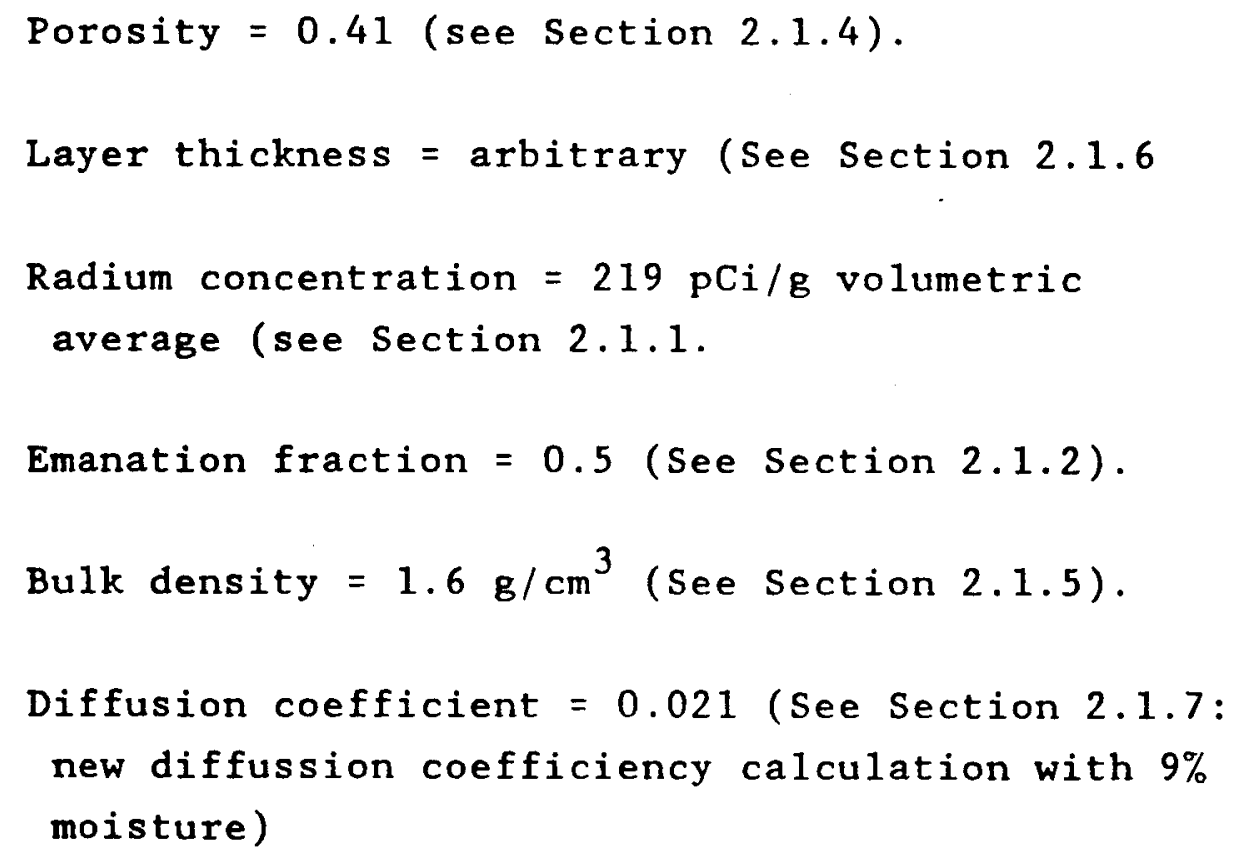

The $9 \%$ soil moisture content in Area B of the TSA was catculated as follows:

After dewatering:

$\%$ moisture for material above 6 meters $=8 \%($ see Section 2.1.3)
WSQRADON / TXT JOANN
A- 46 
$\%$ moisture for material below 6 meters $=12 \%$ (see Section 2.1.3)

The water table is at 6 meters. (See Section 2.1.3).

TABLE 12 Volumes After Dewatering

Volume 0-6 Meters Volume 6-12 Meters

$\begin{array}{lcc}\text { Sump Zone } & 21,236 \mathrm{~m}^{3} & 17,732 \mathrm{~m}^{3} \\ \text { N.E. Corner } & 16,250 & 0 \\ \text { Haulway Zone } & 5,025 & \frac{0}{17,732 \mathrm{~m}^{3}}\end{array}$

Soils above 6 meters $=71 \%$ (by volume)

Soils below 6 meters $=29 \%$ (by volume)

The TSA soils pile (Area B) will be composed of the same percentage of soils from each 6 meters ( 20 foot) depth interval. Therefore, the volume weighted average moisture content will be $(8 \% \times 0.71)+(12 \% \times 0.28)=9 \%$

The thickness of the layers in Area B of the TSA was determined by assuming that the excavated material will not be placed in layers at the temporary storage area. Instead, it will be piled from left to right. This will allow a temporary cover to be placed over the material as it is stockpiled while leaving only the working face accessible. It was also assumed that the radium in each truck load will be uniformly mixed throughout. Therefore, a layer distinction is not necessary. Nevertheless, a layer thickness of 1.5 meters ( 5 feet) was used so as to be consistent with previous modeling. 
The same argument applies to Area $C$ of the TSA

Area C: Sludge moisture content $=25 \%$ (see Section 2.1.3), assume no change from exisiting conditions.

Porosity $=0.41$ (see Section 5.3.3)

Layer thickness - arbitrary (see Section 5.3.3)

Radium concentration - $41 \mathrm{pCi} / \mathrm{g}$ (see Section 5.3.3)

Emanating fraction - 0.5 (conservative, see Section 2.1.2)

Bulk density - $1.6 \mathrm{~g} / \mathrm{cc}$ (for lack of better, see Section 2.1.5)

Diffusion coefficient - 0.00010 (see Section 2.1.8 no change in assumption for 10.6-12 meter layer)

\subsubsection{Curies per Year From Temporary Storage Area}

The total radon release source term for the TSA was given by Equation 4 with the following parameter values:

Soils Pile:

$$
\begin{aligned}
& \emptyset=374 \mathrm{pCi} / \mathrm{m}^{2} / \mathrm{s} \quad(\text { Sheet } 10) \\
& A_{s}=7,500 \mathrm{~m}^{2}(\text { Area B) }
\end{aligned}
$$

Sludge Pile:

$$
\begin{aligned}
& \emptyset=5 \mathrm{pCi} / \mathrm{m}^{2} / \mathrm{s}(\text { Sheet } 10) \\
& A_{s}=1,250 \mathrm{~m}^{2}(\text { Area C) }
\end{aligned}
$$


Solving Equation 4 with these values:

$$
\begin{aligned}
& T=\left(\sigma \times A_{8}\right)_{80 l i s}+\left(\sigma \times A_{s}\right)_{\text {sludge }} \\
& =((374 \times 7500)+(5 \times 1250)) \frac{\mathrm{pCi}}{8} \times \frac{\mathrm{Ci}}{10^{12} \mathrm{pCi}} \times \frac{3.15 \times 10^{7} \mathrm{~B}}{\mathrm{yr}}
\end{aligned}
$$

$=88.2 \mathrm{Cl} / \mathrm{yr}$

The increased flux will be caused by the total Ra-226 activity concentrated in a smaller volume of material. There will be higher concentrations of Ra-226 in the stabilized volume of soils and a higher concentration in the top 1.5 meters ( 5 feet) as compared to existing conditions.

During the first year, when the quarry material will be relocated from the quarry to the TSA, the soils and sludge piles were assumed to increase in area linearly from zero. The flux is assumed to remain constant for each area at 374 and 5 $\mathrm{pCi} / \mathrm{m}^{2} / \mathrm{s}$, respectively. Therefore, in the first year, the total activity released will be $88 / 2=44 \mathrm{Ci} / \mathrm{y}$.

If left uncovered, the TSA would probably cause increased radon concentrations at stations $R D-3003$ and $R D-3004$. However, the current plan is to keep the contaminated material covered at al1 times with a flexible liner. The working face will be covered at the end of each day with a "blasting mat." This will cut the release rate by about a factor of 10 . 
SHEET 10: Radon Flux From the TSA Soils and Sludge Piles

\begin{tabular}{ccccc}
\hline $\begin{array}{c}\text { Depth } \\
\text { Interval } \\
(\mathrm{m})\end{array}$ & $\begin{array}{c}\text { Moisture } \\
\text { Content } \\
(\%)\end{array}$ & $\begin{array}{c}\text { Ra-226 } \\
\text { Concentration } \\
(\mathrm{pCi} / \mathrm{g})\end{array}$ & $\begin{array}{c}\text { Diffusion } \\
\text { Coefficient } \\
\left(\mathrm{cm}^{2} / \mathrm{s}\right)\end{array}$ & $\begin{array}{c}\text { Radon } \\
\text { Flux } \\
\left(\mathrm{pCi} / \mathrm{m}^{2} / \mathrm{s}\right)\end{array}$ \\
\hline
\end{tabular}

\section{Soils Pile}

$\begin{array}{lllll}0.0-1.5 & 9 & 223 & 0.021 & 374.4^{(a)} \\ 1.5-3.0 & 9 & 223 & 0.021 & 83.4 \\ 3.0-4.6 & 9 & 223 & 0.021 & 17.8\end{array}$

\section{Sludge Pile}

$\begin{array}{lllll}0.0-0.8 & 25 & 41 & 1 \times 10^{-4} & 4.8(a) \\ 0.8=1.6 & 25 & 41 & 1 \times 10^{-4} & 0.0 \\ 1.6-2.5 & 25 & 41 & 1 \times 10^{-4} & 0.0\end{array}$

(a) Flux emanating from the surface of the soils and sludge piles is 374.4 and $4.8 \mathrm{pCi} / \mathrm{m}^{2} / \mathrm{s}$ respectively.

The following parameters are assumed to be the same in each depth interval:

$\begin{array}{ll}\text { Porosity } & =0.41 \\ \text { Emanting fraction } & =0.5 \\ \text { Density } & =1.6 \mathrm{~g} / \mathrm{cm}^{3}\end{array}$


REFERENCES

Berkeley Geosciences Associates, 1984. Characterization and Assessment for the Weldon Spring Quarry Low-Leve1 Radioactive Waste Storage Site. DOE/OR-853. Prepared for the U.S. Department of Energy, Oak Ridge Operations Office. September.

BGA, see Berkeley Geosciences Associates.

Gilbert, T.L., C.Yu, Y.C. Yuan, A.J. Zielen, M.J. Jusko, and A. Wa110 III, 1989. A Manual for Implementing Residual Radioactivity Guidelines: A Supplement to U.S. Department of Energy Guidelines for Residual Radioactive Material at Formerly Utilized Sites Remedial Action Program and Surplus Facilities Management Program Sites. ANL/ES-160; DOE/CH/8901. Prepared for the U.S. Department of Energy, Assistant Secretary for Nuclear Energy, Office of Remedial Action and Waste Technology, by ARgonne National Laboratory, Argonne, IL. June.

MKE, see Morrison-Knudsen Engineers.

MKF and JEG, see MK-Ferguson Company and Jacobs Engineering Group.

MK-Ferguson Company and Jacobs Engineering Group, 1989. Remedial Investigations for Quarry Bulk Wastes, Rev 0 . 5121R-303-066. Prepared for the U.S. Department of Energy, Oak Ridge Operations Office, Weldon Spring Site Remedial Action Project.

Morrison-Knudsen Engineers, 1989. WSSRAP Quarry Preliminary Design Report. Report No. 5121R-304-00. San Francisco. May.

WSQRADON / TXT JOANN 
Peck, R.B., W.E. Hanson, T.H. Thornburn, 1974. Foundation Engineering; Second Edition. John Wiley and Sons. New York.

Rogers, V.C. and K.K. Nielson, 1981. A Handbook for the Determination of Radon Attenuation Through Cover Materials. NUREG/CR-2340, RAE18-1, PNL-4084. Prepared for the U.S. Nuclear Regulatory Commission by Rogers and Associates Engineering Corporation. 


\section{DISTRIBUTION LTST}

U.S. Environmental Protection Agency Region VII

Mr. Gale Wright, Chief ( 3 copjes)

Remedial Section/Superfund Branch

U. S. Environmental Protection Agency

Region VII

725 Minnesota Avenue

Kansas City, KS 66101

Missouri Department of Natural Resources

Mr. Dave Bedan ( 3 copies)

State of Missouri

Department of Natural Resources

Post offjice Box 176

Jefferson City, MO 65102

Argonne Nationa1 Laboratory.

Mr. John Peterson

Energy and Environmental. Systems Division

Argonne National Laboratory

9700 South Cass Avenue, Building 362

Argonne, II, 60439

Oak Ridge Operations

B.J. Davis

U.S. Department of Energy

Environmental Protection Agency

Oak Ridge Operations office

Post Office Box 2001

Dak Ridge, TN 37830

Oak Ridge National Laboratory.

Mr. Park Owen

Remedial Action Program Information Center

Oak Ridge National Laboratory

Martin-Marietta Energy Systems, Tnc.

Post Office Box $X$

Oak Ridge, TN 37831

Office of Scientific and Technical Jnformation (2 copies)

U.S. Department of Energy

Post Office Box 62

Oak Ridge, TN 37831

WSQRADON / TXTJOANN 
Oak Ridge Associated Universities

Mr. J.D. Berger

Oak Ridge Associated Universities Post Office Box 117

Building 1916-T2

Oak Ridge, TN 37831-0117

\section{Repositories}

Cobbs Hall

Lindenwood College

St. Charles, MO 63301

Kathryn Linneman Branch

St. Charles City/County Library

$2323 \mathrm{E} 1 \mathrm{~m}$ Street

St. Charles, MO 63301

Spencer Creek Branch

St. Charles City/County Library

425 Spencer Road

St. Peters, MO 63376

Mr. Dan Brown

Francis Howell High School

7001 Highway 94 South

st. Charles, MO 63303

Administrative Record

WSSRAP Public Document Room

7295 Highway 94 South

St. Charles, MO 63303

WSQRADON/TXTJOANN 